\title{
Effect of Infrastructure Investment and Freight Accessibility on Gross Domestic Product: A Data-Driven Geographical Approach
}

\author{
Maria Jubiz-Diaz $\mathbb{D}^{1},{ }^{1}$ Maria Saltarin-Molino, ${ }^{2}$ Julian Arellana $\mathbb{D}^{3},{ }^{3}$ \\ Carlos Paternina-Arboleda ${ }_{(D)}{ }^{1,4}$ and Ruben Yie-Pinedo $\left.{ }^{1}\right)^{1}$ \\ ${ }^{1}$ Department of Industrial Engineering, Universidad del Norte, Km 5 Via Puerto Colombia, Barranquilla, Colombia \\ ${ }^{2}$ Sanofi Aventis, Calle 50 Evolution Tower, Panama City, Panama \\ ${ }^{3}$ Department of Civil Engineering, Universidad del Norte, Km 5 Via Puerto Colombia, Barranquilla, Colombia \\ ${ }^{4}$ Department of Management Information Systems, Fowler College of Business, San Diego State University, 5500 Campanile Dr., \\ San Diego, CA 92182, USA \\ Correspondence should be addressed to Maria Jubiz-Diaz; jubizm@uninorte.edu.co
}

Received 8 February 2021; Revised 11 August 2021; Accepted 13 August 2021; Published 2 September 2021

Academic Editor: Chansung Kim

Copyright (C) 2021 Maria Jubiz-Diaz et al. This is an open access article distributed under the Creative Commons Attribution License, which permits unrestricted use, distribution, and reproduction in any medium, provided the original work is properly cited.

\begin{abstract}
Freight transportation can be defined as the movement of goods and services to customers to obtain a monetary reward. Poor quality transport infrastructure implies higher travelling times and costs. This indirectly affects the productivity of a region since transportation costs are directly related to sales prices. Therefore, infrastructure investments become important for improving the competitiveness of a region. The problem with these investments is that they take time and require a large amount of money. Consequently, it is extremely important to prioritise this type of investment. This paper will first explain whether transportation investment or a sustainable transportation method affect the exported freight accessibility and if it also affects regional productivity using a linear regression model with the aid of a data-driven geographical information system. It uses spatial separation, gravity, and cumulative opportunity measures to calculate accessibility. Finally, the paper denotes which regions are highly affected by improvements in road, river, and railway networks using Colombia as a case study. The comparison considers travelling time and costs savings under each scenario. The results indicate that the gravity measure was the most appropriate accessibility measure for analysing the Gross Domestic Product (GDP). The scenario analyses suggest that zones farthest from the seaports are more sensitive to accessibility changes; consequently, they will receive higher improvements in their regional GDP with a national-level implementation of transport infrastructure investments. Thus, project prioritisation should be performed in regions where the investments lead to a decreased travel cost between regions and ports.
\end{abstract}

\section{Introduction}

Transportation plays an important role in a country's economy and provides opportunities for production and consumption since it implies moving goods and services to customers or transporting passengers to a specific activity. However, transport costs correspond to the highest expenses of companies and lead to time and cost savings to users [1]. Therefore, it is important to reduce both transport cost and time because they indirectly increase the real incomes of society and the competitiveness of a country [2]. That is why governments spend large investments and implement public policies focused on improving the quality of the transport system. Indeed, transport infrastructure investment has been a key element within national development policies of different countries [3]. According to Laird and Venables [1] and Halaszovich and Kinra [4], investment in transport improves productivity, creates growth, impacts land use, affects employment levels, promotes trading and foreign investment, and overcomes the costs of geographic distance. Also it reduces transport cost and companies' revenues increase, which leads to better labour positions and increased investments in business projects that directly improve the economy. Moreover, several authors suggest the use of accessibility measures to represent the relationship between transport infrastructure investment and economic growth [3]. When transport systems are efficient, they provide opportunities focused on the communities' welfare in both economic and social contexts 
that result in positive multiplier effects, such as better accessibility to markets, employment, and additional investments.

According to Vickerman [5], accessibility is a measure of the cost incurred by companies and users for accessing a particular market. It is usually represented as the sum of weighted costs for travelling among different locations. Therefore, a change on these costs in one link will modify the distribution of all trips in the transport network. As a consequence, an enhancement in the accessibility of one location of the transport network affects the global accessibility [3]. For this reason, improving transport and distribution also provides significant changes in production geographies and creates integrated production networks [6]. Another result of reducing transport costs is the effects on supply chain operation because high storage cost has generated supply shortage problems and affected suppliers' service level negatively. A poor quality transport infrastructure implies higher travelling times and costs, which represents an obstacle for export activity. Moreira et al. [7] compared Latin-American countries and concluded that Colombia emerges as the country with the most gain if an improvement in transportation costs is done, as compared to Brazil, Chile, Mexico, and Peru. This means that transport cost represents an important barrier for exports and a region has lower export revenues if exportation activities are located far from seaports with poor quality transportation facilities. Therefore, the country has a low capacity for moving goods to international regions. As was mentioned before, many strategies are commonly applied for enhancing the transport system $[8,9]$. The most common is developing infrastructure investments to expand and improve roads, rivers, and rail networks. According to Sahoo et al. [10], investment in infrastructure stimulates economic activities, reduces both transaction and trade costs, improves competitiveness, and creates employment opportunities. Therefore, investment in transport infrastructure provides access to a broader market base, therefore yielding economies of scale in production and distribution and improving consumption.

Emerging economies are characterised by limited resources for infrastructure investment. One way to prioritise and identify the most suitable investments for a country is through the impact they have on accessibility and economic growth as measured by GDP. Therefore, the aim of this paper is to propose a methodology based on econometric models and geographic information to determine the relationship between infrastructure investment, accessibility, and both regional and national productivity. Colombia will be used as a case study to exemplify the results. The rest of the paper is organised as follows. Section 2 presents the related studies about infrastructure investment and economic growth. Section 3 introduces the proposed methodology. Section 4 develops a case study of the Colombian infrastructure. Finally, Section 5 describes the conclusions and future works.

\section{Literature Review}

The economic impact of investment in infrastructure has been widely studied in the literature since transportation infrastructure is vital for the logistics operation of a country.
These impacts can be estimated using different approaches: Cost-Benefit Analysis (CBA), Computable General Equilibrium (CGE) models, and econometric analysis, such as structural equation model and regression model [11]. Recently, Robson et al. [12] developed a review of the CBA and CGE modelling applied to transport issues and appraisal.

CBA consists of comparing all the monetary benefits before and after an investment rather than estimating the wider impacts on the whole economy of a region [11]. This approach is microeconomic since it is focused on the productivity of individual firms rather than boarder effects of transport infrastructure investment [13]. Some variables used to measure the benefits are travel time, cost saving, and reduction in the number of accidents and externalities associated with transport such as pollution, noise, and greenhouse gases. Wen and Chen [14] presented a CBAbased methodology to analyse the economic growth of China considering economic, social, and ecological variables. Expenditure, public infrastructure, and net capital investment were considered in the first group. Ali et al. [15] proposed a framework to evaluate a new high speed railway (HSR) between Cairo and Alexandria considering only passenger operation. They included air pollution, road accidents, and time saving as externalities for the railway project. Martens and Di Ciommo [16] assessed transport projects considering travel time savings and the equity effects of accessibility gains. Henke et al. [17] developed a sustainable evaluation method for investment in a new HSR in Italy based on CBA.

CGE models are a set of structural equations that describe the interactions between different variables related to transport systems. Many authors have used this type of model to measure the impact of infrastructure investment on economic growth. However, these models need detailed and accurate data, which is not available in most of the cases [11]. Kim et al. [18] developed a framework composed of a transport model and a multiregional CGE model to estimate the economic effects of a new HSR on GDP, price, exports, and population of a region in Korea. Similarly, Kim et al. [19] proposed a financial CGE model to analyse the economic impact of infrastructure projects on the growth in Indonesia, relating the expenditures with financial resources. Hansen [20] developed a spatial CGE to quantify the economic benefits of infrastructure investments in Norway considering commodity flows, competition, and passenger transportation, among other infrastructure-related variables. Chen [21] introduced a CGE-based framework for assessing the impact of HSR on the growth rate of GDP in China. Hiramatsu [22] studied the effects of HSR on tourism of several Japanese regions using a CGE model.

The most common methods used to quantify the impact of infrastructure investment are the economic analyses where transportation infrastructure is considered as the input of the model and variables related to the economic development are the explained variables [11]. Among the different types of economic analysis, the structural equation models (SEM) provide a relationship among variables such as accessibility, logistic efficiency, and port demand. However, this model needs a significant amount of different 
latent variables. Munim and Schramm [23] proposed a SEM to evidence the impact of port infrastructure quality on logistics performance by dividing countries into groups according to their economic growth conditions. Duzbaievna Sharapiyeva et al. [24] conducted a similar study but applicable on landlocked countries. SEM also can consider the public investment as an endogenous variable. Deng et al. [25] applied a SEM to develop a relationship between port supply, port demand, and regional economy in China. Jiang et al. [26] also applied SEM for an empirical analysis between multimodal transportation investment and economic development.

The other types of economic analyses are the regression models that measure the wider impacts of new infrastructure investments on the whole economy. The most widely used model in this group is the production function (Cobb-Douglas function) estimated with the traditional ordinary least squares (OLS) method. The purpose of this model is to represent the relationship between public budget and independent variables (such as infrastructure investment). Aschauer [27] was one of the first authors to propose a production function for relating aggregate productivity and government expenditures variables based on a generalised Cobb-Douglas function and OLS method. Karlsson and Pettersson [28] performed an empirical study of the relationship between the gross regional product and accessibility to educated labour. These authors first estimated a cross-sectional model using OLS method and then implemented a panel data model with time distance access to local labour force. Yamaguchi [29] developed a cross-sectional analysis among the interregional accessibility, GDP growth, and infrastructure development in air transportation. They estimated a Cobb-Douglas production function considering labour, private stock, and air transport accessibility index. Fan and Chan-Kang [30] studied the impact of road investments on economic growth and poverty reduction using an econometric model that relates GDP with labour productivity, employment, and poverty variables. Dercon et al. [31] estimated an instrumental variables model to analyse if the improvements in road quality and agricultural services extension led to a consumption growth and poverty reduction in Ethiopia. Martín-Barroso et al. [32] tested the impact of accessibility to workers and commodities on the productivity of manufacturing companies in Spain using a Cobb-Douglas production function. Baños et al. [33] analysed road infrastructure effects on the productivity of Spanish economy. They estimated a production function using spatial econometric models and an accessibility measure. Itoh [34] evaluated the impacts of improvements in freight transport on logistics accessibility among Japanese regions as an indicator of regional economy using a production function. Martín-Barroso et al. [35] analysed the effects of accessibility on manufacturing companies' productivity using a Cobb-Douglas production function estimated with the OLS method. The considered variables were related to specific features of each company, such as labour, capital, and efficiency level. Salas-Olmedo et al. [36] also proposed a model based on the OLS method to quantify the impact of road new infrastructure on accessibility measures.
$\mathrm{Ng}$ et al. [37] developed a linear regression analysis to determine how improvements in road accessibility affect the GDP as a measure of economic growth. They also considered education expenditures, physical capital stock, and urbanisation levels.

Some studies have used other types of modelling for analysing economic growth. Agbelie [38] estimated a Translog production function to measure the economic impact of highway and railway infrastructure expenditures across a wide variety of countries. Three different statistical approaches were used to estimate the statistical function: OLS, random-effects model (REM), and random-parameters model (RPM). Van den Heuvel et al. [39] developed a partial least square path (PLS) model to study the relationship between freight accessibility and logistics employment in the USA and focused on road, rail, air, and maritime transportation. Verhetsel et al. [40] used a multinomial logit (MNL) model using travel time indicators for assessing the impact of accessibility on the location decision process. $\mathrm{Ng}$ et al. [41] analysed the positive effect of road infrastructure development on economic growth, using road length per thousand population as explained variable in a panel data and REM.

Literature reveals that the interaction between economic growth and infrastructure investment can be described with accessibility indicators that include both agglomeration of economic activity and infrastructure networks. As was mentioned before, accessibility is usually measured as the total cost between any origin and destination using the transport network. Rokicki and Stepniak [3] stated that a change in accessibility leads to a relocation of economic activities because a decrease in transport costs encourages agglomeration and, in consequence, an improvement of the productivity level of a region. Venables [42] concluded that if travel times are reduced, the labour force would be motivated to work longer hours and the labour market becomes more dynamic. Ribeiro et al. [43] found a positive correlation between the population growth and the reductions in travel times given the transport infrastructure investment. Rietveld [44] stated that companies also will benefit from an improvement of accessibility due to a decrease in transport costs since the last one leads to a fragmentation of the production process. In addition, according to Karlsson et al. [45], investment in transport infrastructure enhances both interregional and international accessibility because knowledge imported from other countries improves productivity. Linneker and Spence [46] found that improving accessibility motivates companies to expand their markets to more accessible zones. Thus, employment increases. Moreover, Holl [47] showed that companies choose locations for placing their facilities near to highways. Although the relationship between accessibility, transport costs, and economic development is evident, most studies have modelled this relationship from the user's viewpoint. Studies on this field generally used domestic air transport [29], labour [32], highways and railways [33,48], interregional logistics [34], road mobility [37], travel time [3], location [49], among others, as main indicators. According to Khalili et al. [50], freight accessibility for measuring the effect of 
investment in transport systems on economic growth has rarely been considered in the literature, as shown in Table 1.

Thomas et al. [51] studied how this accessibility relates with the consumption and production of goods in Belgium based on three impedance functions to analyse topological, geographical, and economic accessibility. They compared the accessibility measures before and after changes were made in the infrastructure and concluded that the distribution of activities is more associated with population rather than transport infrastructure. Bowen Jr. [52] analysed the relationship between freight accessibility and the number of warehouses in certain zones in the United States using a geographical comparison of the distribution of warehousing establishments between 1998 and 2005. Infrastructure-based measures were applied for roads and rail, while distancebased measures were applied for maritime and air transport modes. The main findings stated that warehouses are highly correlated with air and road accessibility whereas it has a lower impact on rail and maritime accessibility. Lim and Thill [53] investigated the effects of intermodality on freight accessibility in the United States, measured as the ability that regions have to position themselves in the national economy. The authors developed a geographically weighted regression (GWR) model to identify the variables that improve intermodal accessibility. Concluding remarks stated that intermodality enhances average accessibility overall, but the wider impact is on peripheral regions.

Thill and Lim [54] extended the study performed by Lim and Thill [53]. They analysed how intermodal infrastructure and operations affect freight accessibility in terms of the efficiency in exports that regions of the United States gained as intermodality is implemented. Accessibility measures were compared for highway and intermodal networks. The authors concluded that the intermodal network enhances the connection between regions and ports. As was mentioned, Van den Heuvel et al. [39] analysed the relationship between freight accessibility and logistics employment using different accessibility measures for rail, road, air, and maritime transport considering both metropolitan and nonmetropolitan areas of the United States. Results showed a strong correlation between freight accessibility, logistics employment, and population. Martín-Barroso et al. [35] used indicators related to workers and commodities combined with transport and land use to evaluate the impact of accessibility on the productivity of manufacturing companies in Spain. They developed a Cobb-Douglas production function considering variables of international trade strategies and companies' specific features. The results showed that manufacturing firms are highly correlated with accessibility to commodities rather than accessibility to workers.

Salas-Olmedo et al. [36] integrated freight accessibility, border effects, and multilateral resistance. These authors proposed a two-step model to represent the bilateral trade among European countries in function of the market size (measured as GDP), distance, and travel times and assessed the importance of each region and its potential contribution to other markets. They concluded that transportation investment enhances average accessibility overall, but the wider impact is on peripheral regions. As mentioned before,
Verhetsel et al. [40] used discrete choice modelling to quantify the impact of freight accessibility on the location decision process of logistics companies that deal with material flows of goods in Flanders (Belgium). The proposal considered road, rail, inland navigation, and port access. Results of the experiments stated that logistic companies must be established on high accessible locations and they have a strong preference for locations near to intermodal and multimodal transport.

Africani et al. [55] developed a methodology to evaluate regional issues regarding freight accessibility between Karlsruhe (Germany) and Liguria (Italy). The study provided an overview about logistics accessibility including forwarders and both terminal and infrastructure operators. The authors identified weakness especially in road traffic due to poor infrastructure. Guo and Yang [56] evaluated the accessibility of overseas regions in China regarding shipping connectivity and access to markets. The authors developed a new accessibility index called foreign trade transport accessibility (FTTA) as a measure of the transportation impedance of exported goods and trading opportunities. As a result, this study is a basis to formulate trade policies that promote exports and shipping industries. Khalili et al. [50] proposed a new approach to evaluate and compare freight accessibility conditions in several regions of Iran using centrality and reliability measures. The authors concluded that the proposed approach provides information about the relative position of regions regarding freight accessibility and how they change as transportation investment is made.

Previous models addressed the effect of public investment on economic development using different empirical analysis. As an example, Halaszovich and Kinra [4] described the impact of national transportation systems on international trade and foreign direct investments. They show that the elements of national transportation systems positively influence both trade and FDI (Foreign Direct Investment). Also, they found support for the notion that the nature of the transportation costs differs between trade and FDI. While trade is related to international transportation and port infrastructure, FDI is based on within-country transportation and is moderated by land-based transportation infrastructure. In a previous work, Lopez et al. [57] presented the incidence of the investment on river transportation in the success of a multimodal transportation model, leading to an increase in logistics competitiveness of a region to directly improve logistical performance in the supply chains for the different regions and agricultural sectors. In addition, Marzuez et al. [58] developed an approach based on geographical analysis to include accessibility indicators as explanatory variables in the freight generation models, in order to analyse the impact that new transport infrastructure produces in agricultural production.

However, to the best of the authors' knowledge, no study has related freight accessibility with the GDP to represent economic growth given transport infrastructure investment. Also, it is suitable to mention that none of these studies were applied in Latin-American countries. Therefore, the aim of this paper is to propose a methodology to analyse the effect of infrastructure investment on the GDP using the freight 
TABLE 1: Review of related studies.

\begin{tabular}{|c|c|c|c|c|c|}
\hline Authors & Related variables & $\begin{array}{c}\text { Accessibility } \\
\text { measure }\end{array}$ & Strengths & Weaknesses & Conclusions \\
\hline $\begin{array}{l}\text { Thomas } \\
\text { et al. [51] }\end{array}$ & $\begin{array}{c}\text { Transport } \\
\text { infrastructure and } \\
\text { economic activities }\end{array}$ & Gravity-based & $\begin{array}{l}\text { (1) The generalised cost } \\
\text { and topological measures } \\
\text { are highly correlated, (2) } \\
\text { each node is characterised } \\
\text { by an accessibility } \\
\text { measure for each } \\
\text { transportation system, } \\
\text { and (3) the proposed } \\
\text { methodology leads to } \\
\text { building global policies } \\
\text { for each cluster }\end{array}$ & $\begin{array}{l}\text { (1) Safety and reliability } \\
\text { were not included in the } \\
\text { generalised cost, (2) the } \\
\text { geographical accessibility } \\
\text { contains a theoretical } \\
\text { congestion rather than an } \\
\text { observed one, and (3) the } \\
\text { economic accessibility } \\
\text { must contains the real } \\
\text { commodity flows entering } \\
\text { and/or leaving each node }\end{array}$ & $\begin{array}{l}\text { Transport infrastructure is } \\
\text { more closely related to } \\
\text { population growth rather } \\
\text { than to economic } \\
\text { activities }\end{array}$ \\
\hline $\begin{array}{l}\text { Bowen Jr. } \\
{[52]}\end{array}$ & $\begin{array}{l}\text { Freight accessibility } \\
\text { and number of } \\
\text { warehouses }\end{array}$ & $\begin{array}{l}\text { Infrastructure- } \\
\text { based and } \\
\text { distance-based }\end{array}$ & $\begin{array}{l}\text { Different accessibility } \\
\text { measures were designed } \\
\text { for each transportation } \\
\text { system (air, maritime, } \\
\text { highway, and rail) }\end{array}$ & $\begin{array}{l}\text { The relationship between } \\
\text { warehousing and } \\
\text { transportation } \\
\text { accessibility was } \\
\text { calculated using } \\
\text { correlation analysis rather } \\
\text { than regression models }\end{array}$ & $\begin{array}{l}\text { Number of warehouses is } \\
\text { strongly correlated with } \\
\text { air and highway } \\
\text { accessibility while it has a } \\
\text { low correlation with rail } \\
\text { networks }\end{array}$ \\
\hline
\end{tabular}

The measure of economic opportunity as the

(1) A GWR model was Intermodal freight

Lim and Thill [53] transport network and freight accessibility

Gravity-based estimated to perform a sensitivity analysis of different scenarios and (2) results of OLS and GWR were compared

combination of personal consumption expenditure and purchases of manufactured goods was not available at local geographic scale

(1) The measure of economic opportunity as the combination of

(1) Intermodal and highway accessibility measures were calculated separately and (2) a Thill and network and freight $\operatorname{Lim}[54]$ transportation market

Gravity-based sensitivity analysis was performed to evaluate the effect of transport intermodality on freight accessibility

personal consumption purchases of manufactured goods was not available at local geographic scale and (2) exponential impedance functions of travel cost expenditure and were used with three different hypothetical values of the parameters

(1) Accessibility measures are based only on average travel times (i.e., they do not consider the variability), (2) the

A total landed weight was used to calculate air and maritime accessibility

$\begin{array}{lc}\text { Van den } & \text { Freight accessibility } \\ \text { Heuvel } & \text { and logistics } \\ \text { et al. [39] } & \text { employment }\end{array}$

Gravity-based based on the cargo moved by 25 airports and seaports of the United States maritime, road and rail accessibility were

calculated separately, and (3) data about cargo handled in rail terminals was not available so rail accessibility uses the number of intermodal rail
Intermodal network enhances average accessibility overall but the wider impact is on peripheral regions
Intermodal network enhances the connection between regions and ports terminals 
TABle 1: Continued.

\begin{tabular}{|c|c|c|c|c|c|}
\hline Authors & Related variables & $\begin{array}{c}\text { Accessibility } \\
\text { measure }\end{array}$ & Strengths & Weaknesses & Conclusions \\
\hline $\begin{array}{l}\text { Martín- } \\
\text { Barroso } \\
\text { et al. [35] }\end{array}$ & $\begin{array}{l}\text { Freight and worker } \\
\text { accessibility with } \\
\text { productivity of } \\
\text { companies }\end{array}$ & $\begin{array}{l}\text { Gravity-based } \\
\text { and distance- } \\
\text { based }\end{array}$ & $\begin{array}{l}\text { (1) The impedance } \\
\text { functions were estimated } \\
\text { using probability } \\
\text { functions with microdata } \\
\text { to identify the individual } \\
\text { features of both workers } \\
\text { and firms and (2) the } \\
\text { relationship between } \\
\text { productivity in } \\
\text { manufacturing firms and } \\
\text { accessibility were } \\
\text { determined using a } \\
\text { production function }\end{array}$ & $\begin{array}{l}\text { (1) Accessibility for } \\
\text { workers is based on the } \\
\text { number of potential } \\
\text { workers living in a generic } \\
\text { municipality; therefore } \\
\text { the methodology does not } \\
\text { consider the real data, and } \\
\text { (2) congestion in the area } \\
\text { of study (metropolitan) } \\
\text { was not included }\end{array}$ & $\begin{array}{l}\text { Manufacturing firms are } \\
\text { highly correlated with } \\
\text { accessibility to } \\
\text { commodities }\end{array}$ \\
\hline
\end{tabular}

(1) The border effect and factors related with international trade were considered and (2) integrating the role of Transport

Salas-

Olmedo

et al. [36] improvement on economy and accessibility considering borders effects
Gravity-based

competition, the effects of borders, and distance decay with real data provides a richer

perspective than the fixed effect or price indices approaches
(1) The internal travel time within each region was calculated using estimated internal distances and speeds and (2) the GDP was used as a proxy variable to calculate the accessibility measure, instead of using export flows between countries
Transportation investments enhance average accessibility overall but the wider impact is on peripheral regions
Verhetsel et al. [40]
Accessibility and location of logistic companies
Distance-based d
(1) A linear, a part-worth MNL and a linear with part-worth MMNL model were designed and compared and (2) a choice experiment was used to quantify the trade-offs managers of logistics companies for choosing among alternative site locations

\section{(1) Attractiveness measures were not considered in freight accessibility, (2)}

accessibility measure only considers the distance to major transport infrastructure, (3) the calculation of the willingness to pay was not available in the study, (4) results have an unknown mean and standard deviation, and (5) maritime, road, and rail accessibility were calculated separately, instead of combining them in one measure

(1) The methodology considers quantitative and qualitative data such as the quality of both

Africani et al. [55]
Freight accessibility and infrastructure issues
Distance-based infrastructure and supply

of logistic services and (2) accessibility measure was calculated and compared for regions along corridors instead of
(1) Attractiveness measures were not considered in freight accessibility and (2) the accessibility measure only considered the distance to major transport infrastructure
Logistic companies strongly prefer locations near to intermodal and multimodal transport
Road traffic is the main problem that affects regional accessibility 
TABle 1: Continued.

\begin{tabular}{|c|c|c|c|c|c|}
\hline Authors & Related variables & $\begin{array}{c}\text { Accessibility } \\
\text { measure }\end{array}$ & Strengths & Weaknesses & Conclusions \\
\hline $\begin{array}{l}\text { Guo and } \\
\text { Yang [56] }\end{array}$ & $\begin{array}{l}\text { Access to markets } \\
\text { and foreign trade } \\
\text { transport } \\
\text { accessibility }\end{array}$ & $\begin{array}{l}\text { Foreign trade } \\
\text { transport }\end{array}$ & $\begin{array}{l}\text { (1) A new accessibility } \\
\text { index was proposed } \\
\text { considering trade } \\
\text { attractiveness measure } \\
\text { and a generalised cost } \\
\text { function that helps } \\
\text { decision-makers to } \\
\text { optimize ports and } \\
\text { shipping industries and } \\
\text { (2) the path choice } \\
\text { behaviour of shippers was } \\
\text { analysed using a discrete } \\
\text { choice model to measure } \\
\text { the generalised cost } \\
\text { function }\end{array}$ & $\begin{array}{l}\text { (1) The average price of } \\
\text { the shipping lines was } \\
\text { used to measure the } \\
\text { generalised cost of ocean } \\
\text { shipping so it cannot } \\
\text { reflect the impact of price } \\
\text { deviations among various } \\
\text { shipping lines on the } \\
\text { generalised cost and (2) } \\
\text { the FTTA measure does } \\
\text { not consider the } \\
\text { importance of market } \\
\text { scales, transport } \\
\text { impedance, and the } \\
\text { stochastic choice } \\
\text { behaviour of shippers }\end{array}$ & $\begin{array}{l}\text { Foreign trade transport } \\
\text { accessibility is affected by } \\
\text { the hinterland access } \\
\text { system, shipping network, } \\
\text { and markets achieved by } \\
\text { foreign trading partners }\end{array}$ \\
\hline
\end{tabular}

(1) Two new accessibility measures were designed considering the variability of travel time and the tardy freight percentage to provide insights about the impacts of interventions in the transport network and (2) a bidimensional diagram was used to represent accessibility measures that helps authorities to identify the regions where freight accessibility problems are more severe
(1) The impact of the freight shipped from each region and/or to each region on the obtained results was not analysed and (2) only 31 main zones were used in the study instead of all the 124 freight zones
Proposed accessibility measures assist transport authorities in decisions about road conditions and networks' evolution
[50] Centrality and
reliability

$$
\begin{aligned}
& \text { conditions of } \\
& \text { different regions }
\end{aligned}
$$

demand among regions and seaports as a measure of accessibility. This study provides a basis to prioritise transport infrastructure improvements considering the limited resources that governments have, especially in Latin-American countries.

\section{Methodology Description}

The proposed methodology for measuring the effect of infrastructure investment on GDP consists of the following phases.

\subsection{Phase I: Constructing Freight Accessibility Measures.} The first phase of the proposed methodology consists of characterising the accessibility conditions of the region under study using the most suitable measures. Geurs and van Wee [59] defined accessibility as "the extent to which land use and transport systems enable companies to receive people, goods and information at different times of a day." Based on this concept, accessibility can be seen from the area in which goods are located and reach users within a specific time or cost. These authors classified accessibility measures into four broad categories: infrastructure-based, location-based, person-based, and utility-based measures [60]. Another overview of accessibility measures was given by Scheurer and Curtis [61]. They grouped them into spatial separation measures, contour measures (also known as cumulative opportunities), gravity measures, and utility models. Several authors have concluded that every proposed measure has its drawbacks and weaknesses, and the choice of the most suitable accessibility index depends on the aim of the study. According to the aim of this paper and the available data for the study, the selected measures were (i) spatial separation, (ii) cumulative opportunities, and (iii) gravity measures. These measures include land use, which is the attraction opportunity, and an impedance function that represents the access restrictions from one area to another. This paper also considers that transport cost is the main restriction for exports in Latin-America and the Caribbean [7].

The spatial separation measure is one of the most used measures in transport geography literature. It aims to analyse the operation of transport systems in terms of time, congestion, and service level of the network between the origins and destinations [60]. This measure only considers the travel time or costs between locations as the input variables of the model. However, it does not consider the 
freight demand, so all nodes of the network have the same weight. Equation (1) presents the form of the spatial separation measure.

$$
A_{i}=\sum_{j=1}^{D} C_{i j}
$$

where $A_{i}$ is the freight accessibility at origin $i, C_{i j}$ is the minimum cost between origin $i$ and destination $j$, and $D$ is the total number of destinations. In this paper, the transport cost from node $i$ to node $j$ is not the unique variable that represents the impedance value [7]. A generalised cost function was computed considering that travel time is also an important factor in freight transportation [62]. The $\mathrm{cu}$ mulative opportunities measure counts the number of opportunities that can be reached within a given travel time, cost, or distance [63]. This model does not capture the variations and differences between activities within the same zone. However, it considers a specific zone or defining catchment area, land use, and an impedance function to calculate the maximum travel time or cost that covers a specific percentage of exported freight, as shown in the following equation:

$$
A_{i}=\sum_{j=1}^{D} T_{i j} \cdot W_{i j},
$$

where $A_{i}$ is the accessibility at origin $i, T_{i j}$ is the freight generated by origin $i$ and attracted by destination $j, W_{i j}$ is a dummy variable ( 1 if $C_{i j}<C_{i j}^{*}, 0$ otherwise), $C_{i j}$ is the transport cost or travel time that represents the minimum measure of the impedance between the origin $i$ and destination $j, C_{i j}^{*}$ is a predetermined threshold, and $D$ is the total number of destinations.

The gravity measure combines the effects of land use, transport infrastructure attributes, and individual perception [60] because both a distance decay function and the potential opportunities are considered. It is the most frequent indicator because it considers the attributes of the network and the characteristics of the activities in the system. It could represent economic accessibility as long as it includes a freight flow between origins and destinations. Equation (3) shows the form of the gravity measure:

$$
A_{i}=\sum_{j=1}^{D} \frac{T_{i j}}{f\left(C_{i j}, \beta\right)},
$$

where $A_{i}$ is the freight accessibility at origin $i, T_{i j}$ is the cargo generated by origin $i$ and attracted by destination $j, f\left(C_{i j}, \beta\right)$ is the impedance function between origin-destination pairs, $C_{i j}$ is the minimum measure of the impedance between origin $i$ and destination $j, \beta$ is a parameter of the model, and $D$ is the total number of destinations. In this particular case of freight transportation, $f\left(C_{i j}, \beta\right)$ is a negative exponential function because the transport cost increases in regions that are far from the destination points. The parameter $\beta$ of the impedance function was estimated using a multinomial logit (MNL) model where the dependent variable was the freight demand and the independent variables were the minimum travel times and the minimum transport costs.
3.2. Phase II: Constructing the GDP Empirical Model. The second phase consists of modelling the relationship between the effects of infrastructure investment and GDP. According to Mankiw [64], GDP is the market value of goods and services produced by a region within its borders in a specific time interval. It is an indicator of the economic activity of an area and can be used to explain the competitiveness differences between regions. Since it is affected by production factors such as labour and capital, the selected variables for the empirical model are (i) labour, (ii) infrastructure investment capital, and (iii) the accessibility measures calculated in Phase I. As was concluded in other studies, a positive relationship between GDP and the independent variables is expected [65-67]. Moreover, a higher GDP is foreseen in those regions with a greater number of employees because a particular supply is needed to generate demand for products in the region. Thus, greater investment in infrastructure increases the demand for products for construction and increases money circulation. Greater accessibility of freight to ports and lower transport costs promote exports from the regions [64].

3.3. Phase III: Analysis of Scenarios. The third phase consists of scenario analyses to interrogate how the GDP increases when different infrastructure projects are implemented. Three scenarios were evaluated:

Scenario 1. Current situation: this scenario assumes that the transport network of the region is not improved

Scenario 2. Road investment situation: this scenario assumes that only the road transport network will be improved

Scenario 3. Multimodal investment situation: this scenario considers multimodal transport improvements using road, rail, and waterway investment projects

The accessibility measures described in Section 3.1 were calculated for the three proposed scenarios.

\section{Case Study: Colombian Infrastructure}

The proposed methodology was applied in a study developed in Colombia. This country is in South America and borders Panama, Brazil, Ecuador, Peru, and Venezuela. Colombia is bathed by both the Atlantic and Pacific Oceans. The exports represent approximately 10289.97 USD ( 1 USD $=3185.40$ COP at July 15,2019$)$ and the GDP per capita is 4441.26 USD. The origin nodes of the transport network correspond to each department of the country. Colombia has 32 departments as shown in Figure 1. However, 28 out of 32 departments were taken as origin nodes of the network because the departments Vichada, Guainía, Vaupes, and Amazonas have low accessibility, poor transport network conditions, and low volume of cargo for exports.

The destination nodes are the main public seaports of Colombia located in the cities Barranquilla (Atlántico), Santa Marta (Magdalena), Cartagena (Bolivar), Tolu (Sucre), 


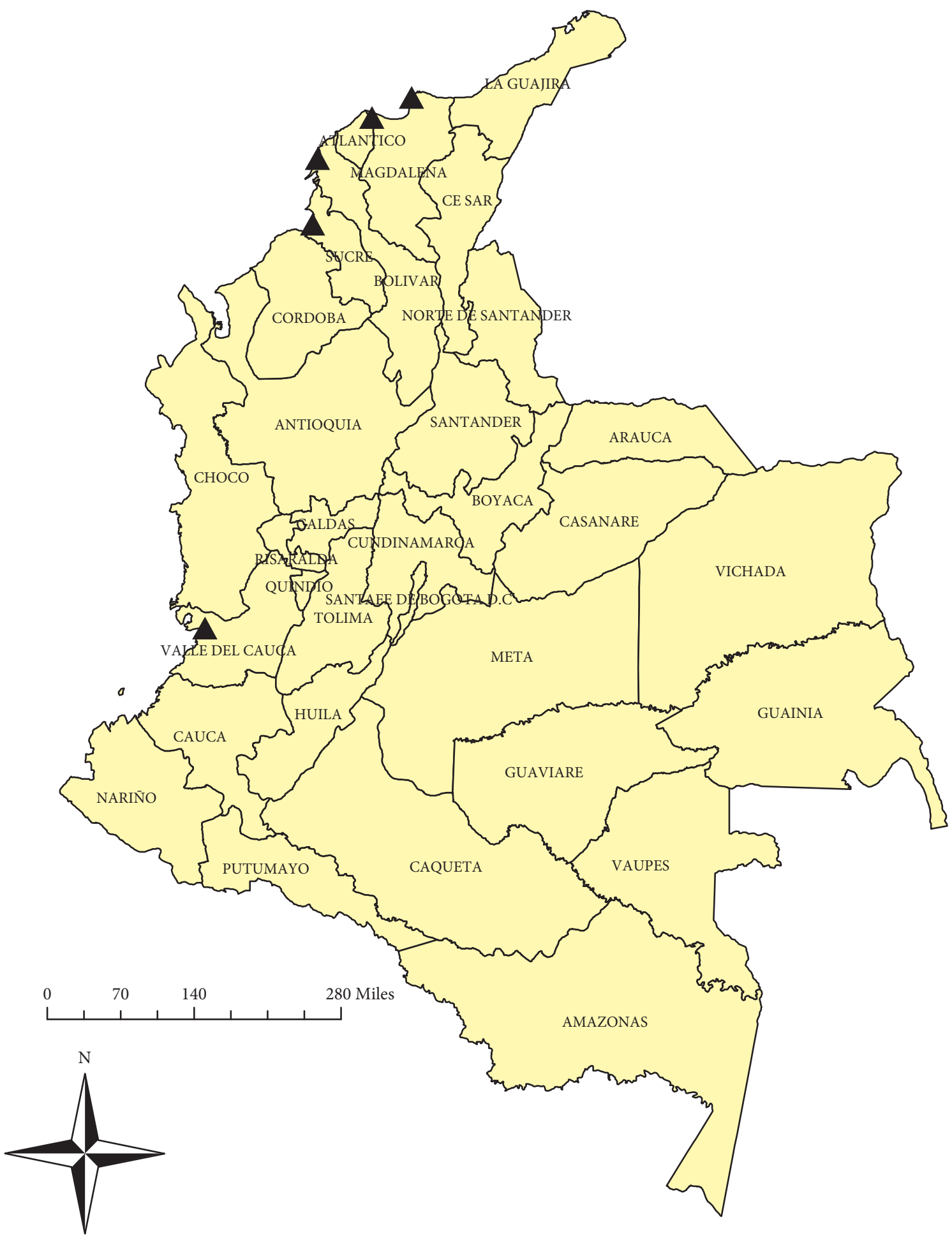

- Seaports

Colombia's Department

Figure 1: Colombian regions.

and Buenaventura (Valle del Cauca). Ports are concessions that provide services to traders to import and export their products by container or bulk. The ports on the Atlantic coast are located in Barranquilla, Santa Marta, Cartagena, and Tolu. The port of Cartagena is the one that mobilises the largest amount of exports according to the Superintendent 
of Ports and Transport of Colombia [68]. In addition, it has the best conditions for larger shipping lines to navigate. The only port located on the Pacific Coast is Buenaventura, which moves the largest amount of imports because it has the infrastructure to move containers with greater agility [69]. Figure 2 presents the location of origin and destination nodes. The transport networks used for this analysis were of three types: fluvial, land, and rail as shown in Figure 2. The fluvial network consists of $3186.8 \mathrm{~km}$, the transport network has $35362.6 \mathrm{~km}$, and the rail network is $4150.54 \mathrm{~km}$ long. The port with direct access to the river network is the one located in Atlántico, while the ports with direct access to the rail network are those located in Magdalena and Valle del Cauca. Currently, in Colombia the use of these modes is not significant in comparison to the use of the land network due to the lack of investment in rail and river infrastructure.

Several investments in infrastructure have been made recently, aiming to directly impact travel time and costs to increase the competitiveness and productivity of the country indirectly [9]. The infrastructure projects and principal interventions that were considered in this study are presented in Table 2.

The following data was also determined:

Freight demand refers to export cargo between regions and ports $\left(T_{i j}\right)$, especially commodities such as coffee, oil, and coal. These data were obtained from the records reported by the Directorate of National Taxes and Customs of Colombia (DIAN) for 2013 and 2014 [70].

Impedance cost corresponds to the sum of transport cost and travelling time. The transport cost considered in this paper is $0.053 \mathrm{USD} / \mathrm{km}$ per ton for road links and it is 1.53 times more expensive for river and rail transport [71]. The cost associated with travel time was estimated using a $0.113 \mathrm{USD} /$ hour per ton subjective value for freight time from a study conducted by Márquez Díaz and Cantillo Maza [72] in 2011. A growth rate was applied, and the value of time was updated to $0.131 \mathrm{USD} /$ hour-ton.

Minimum impedance cost represents the minimum transport cost and the minimum travelling time calculated using the software ArcGIS 10.2.2 with an Allor-Nothing assignment model. In line with Cantillo et al. $[69,73]$, the distances were calculated by ArcGIS geometric calculation, while the cargo speed was extracted using data from INVIAS. The maximum road speed was $40 \mathrm{~km} / \mathrm{h}$ for flat terrain, $22 \mathrm{~km} / \mathrm{h}$ for wavy terrain, and $12 \mathrm{~km} / \mathrm{h}$ for hilly terrain. River transport time is approximately $17 \mathrm{~km} / \mathrm{h}$, while railways speed could vary between $40 \mathrm{~km} / \mathrm{h}$ and $70 \mathrm{~km} / \mathrm{h}$. Additionally, travelling speed increased by $8 \mathrm{~km} / \mathrm{h}$ in double lane highways.

GDP data was obtained from the Regional Report Accounts collected by the National Administrative Department of Statistics (DANE) [74].

Number of employees was obtained from the report of Regional Economic Condition 2013 published by DANE [75].
Infrastructure investment capital was extracted from the Report of Regionalization inversion bud get reported by the National Department of Planning (DNP) [76].

The abovementioned data of transport infrastructure in Colombia can be found on a GitHub repository (see Data Availability for more information).

4.1. Calculating Accessibility Measures. The accessibility measures mentioned in Section 3.1 were calculated for the three scenarios and each department of Colombia. The variation of maximum road speed was applied on the links that are included on road projects mentioned in Figure 3 and railway and waterway projects in Figure 4.

4.1.1. Spatial Separation Accessibility Measure. Figure 5 presents the estimation of the spatial separation accessibility measure, i.e., the generalised transport cost between origin-destination pairs. The generalised cost is the sum of transport cost and travel time, which is the minimum impedance cost. Figure 5(a) shows that the northern regions of the country (blue and green coloured) are the most accessible ones because the principal seaports are near them, so the distances and transport times are shorter compared with the most remote areas. Figures 5(a) and 5(b) show that there is no apparent difference in the spatial separation accessibility measures computed for Scenario 1 and Scenario 2 . The reductions in terms of the generalised cost by investing in road infrastructure projects represent less than 93.83 USD.

Moreover, implementing only road investment projects on the transport network causes most transporters to pay between 187.66 USD and 250.21 USD to reach the seaports. On the other hand, Figure 5(c) shows that investment in multimodal transport projects lets most of the freight transporters reach all seaports with a cost less than 187.66 USD. According to this measure, these multimodal projects would primarily benefit the eastern and central regions of the country.

\subsubsection{Cumulative Opportunities Accessibility Measure.} The $W_{i j}$ dummy variable was estimated for determining the cumulative opportunities accessibility measure using three different thresholds for the minimum generalised cost per ton: 12.51 USD, 25.02 USD, and 37.53 USD. The results considering the cumulative opportunities measures for the three scenarios mentioned in Section 3.3 are presented in Table 3.

This table shows the changes in freight coverage when the improvement in the transport network is implemented (Scenarios 2 and 3). The comparison of freight accessibility in the scenarios using the measure leads to understanding the percentage of freight that is efficiently transported in Colombia. At the country level, road infrastructure projects do not significantly impact freight coverage, which is the same conclusion given by the analysis of the spatial separation accessibility measure. 


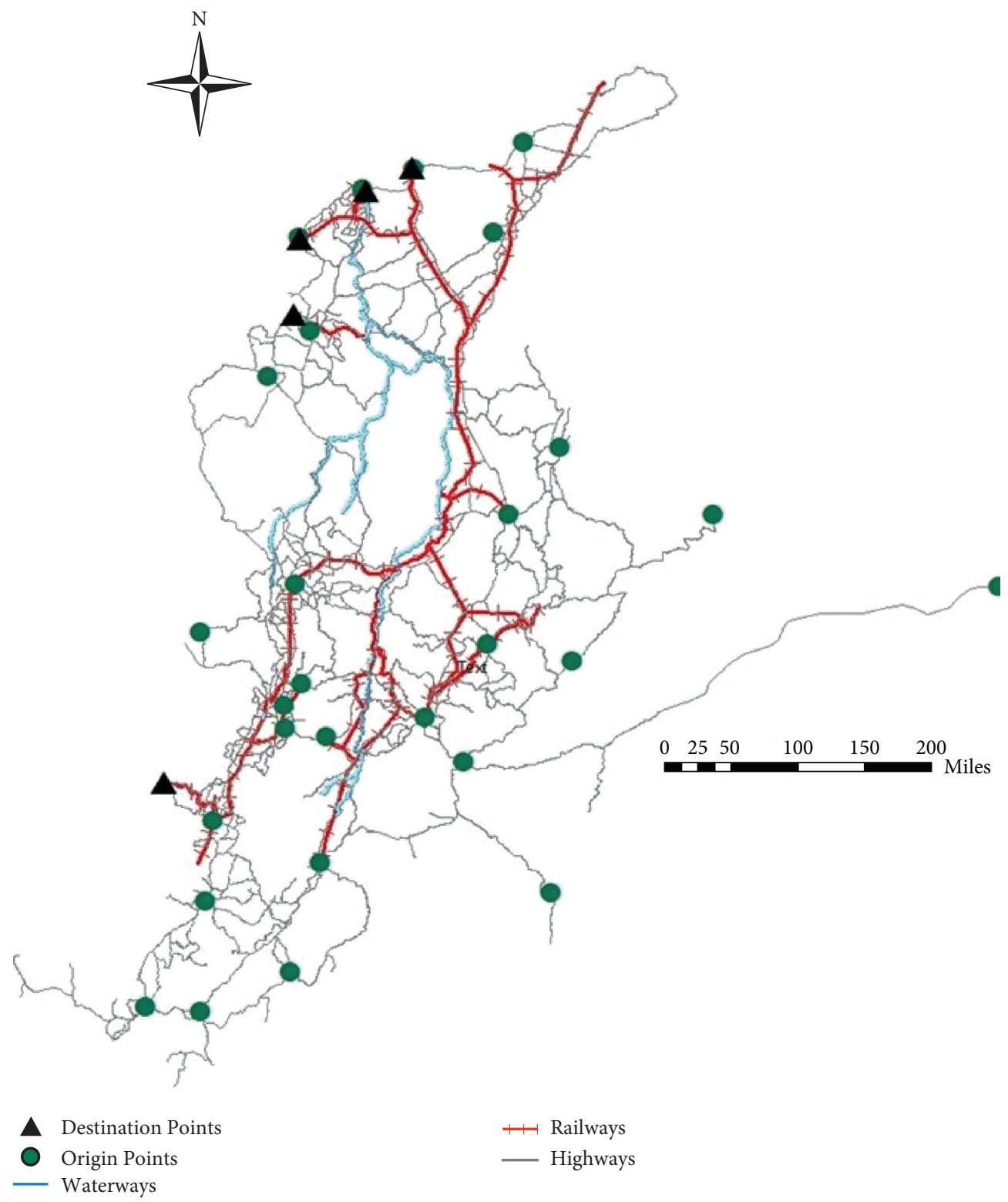

FIGURE 2: Origin-destination points and transport network.

The former means that $59.38 \%$ of the cargo is moved with a cost less than 37.53 USD per ton, regardless of the implementation of road transportation projects. Table 3 also shows that investments in multimodal transport infrastructure are more efficient than in road projects because freight accessibility increases from $59.39 \%$ to $61.35 \%$.

4.1.3. Gravity Accessibility Measure. The gravity accessibility measure was calculated using freight transport demand and an impedance cost function. As mentioned before, the impedance function was estimated using a multinomial logit (MNL) model that defines the utility of moving freight between origin-destination pairs $\left(U_{i j}\right)$ as a function of the transport cost as

$$
U_{i j}=\theta_{i j}+\beta \cdot C_{i j}
$$

This MNL model is estimated using impedance and attraction data from an origin-destination (O-D) matrix. It has 28 origin points (i.e., regions) and 5 destination points (i.e., ports), as shown in Figure 2. The attractiveness data are the tons exported between regions and ports $\left(T_{i j}\right)$ which are the basis for calculating the O-D pair utility $\left(U_{i j}\right)$. The impedance data are the transport costs between O-D pairs, without considering infrastructure projects in the transport network. Time costs and distance costs were included. The sign of this variable is expected to be negative considering the hypothesis that the export quantity increases between O-D pairs if time and distance are smaller between them.

The validity of the MNL model is shown in Table 4 . Using a Berkson-Theil transformation, the relationship between costs per ton follows an upward trend and the number of exports decreases when the minimum impedance cost is over 37.53 USD per ton. This means that the 
TABLE 2: Temperature and wildlife count in the three areas covered by the study.

\begin{tabular}{|c|c|}
\hline Project name & Principal interventions \\
\hline \multicolumn{2}{|l|}{ Road infrastructure projects } \\
\hline Ruta del Sol project & $\begin{array}{c}\text { Double carriageway } \\
\text { New road between Villetas and Puerto Salgar }\end{array}$ \\
\hline Buga-Buenaventura project & $\begin{array}{l}\text { New road between Mulalo and Loboguerro } \\
\text { Road maintenance between Buga and Buenaventura }\end{array}$ \\
\hline Girardot-Honda project & $\begin{array}{l}\text { Double carriageway } \\
\text { Two bridges in Puerto Salgar and Flandes }\end{array}$ \\
\hline Tunja-Puerto Boyaca project & Improvement of the road \\
\hline North Highway connection & Improvement of the road between Zaragoza and Caucasia construction of tunnels \\
\hline Bogota-Villavicencio project & Double carriageway \\
\hline Pacific Highway connection & $\begin{array}{l}\text { Bolombolo-Primavera double carriageway } \\
\text { La Pintada-Bolombolo double carriageway }\end{array}$ \\
\hline \multicolumn{2}{|l|}{ Railway infrastructure projects } \\
\hline Pacific Railway project & $\begin{array}{l}\text { La Felisa-Zaragosa railway } \\
\text { La Tebaida-Zaragosa railway }\end{array}$ \\
\hline North Railway project & $\begin{array}{c}\text { Second railway from Chiriguana to Santa Marta } \\
\text { New railway between La Loma and Puerto Drummond } \\
\text { Maintenance of La Dorada-Chiriguana and Bogota-Belencito railways } \\
\text { Belencito-La Vizcaya and Bogota-Santa Sofia railways } \\
\text { New railway between Chiriguana and Dibulla }\end{array}$ \\
\hline $\begin{array}{l}\text { Fluvial infrastructure projects } \\
\text { Dredging of the Magdalena River }\end{array}$ & Recovery of the river between Puerto Salgar, La Dorada, and Barranquilla \\
\hline
\end{tabular}

probability to move the freight at ports is insignificant when the cost is higher than 37.53 USD per ton.

Therefore, the impedance function is presented in equation (5) and graphically in Figure 6.

$$
f\left(C_{i j}, \beta\right)=\exp \left(1.248-0.0000305 . C_{i j}\right) \text {. }
$$

Figure 6 also suggests that changes in the impedance function are practically null for values of transport cost per ton greater than $37.53 \mathrm{USD} / \mathrm{ton}$. This means that the freight exported in an origin-destination pair in Colombia is lower for regions in which the cost necessary to reach a seaport is greater than 37.53 USD per ton.

Figure 7 shows that the northern and western regions (blue coloured ones) are the most accessible zones due to their closeness to the ports. These results suggest a negative relationship between the transport cost and exported freight demand. Because the gravity accessibility measure considers both transport supply and demand, Arauca (the greencoloured department in Figure 7(a)) has a good accessibility measure. Despite its high transport cost, this department has a high production of oil cargo, which is the most exported product in the country.

Figures 7(a) and 7(b) show that there is no significant difference in freight accessibility when investing in road infrastructure projects. Antioquia (the green-coloured department in the central part of the country Figure $7(\mathrm{~b})$ ) was the only department that benefited due to the road infrastructure investments. In contrast, Figure $7(\mathrm{c})$ reinforces that investing in multimodal projects is worth more than investing only in road transport. Constructing new railways and improving waterway links will cause a higher impact on the ease of transporters from each department to reach the seaports.
4.2. The Empirical Model between GDP and Freight Accessibility. As previously mentioned in Section 3.2, the variables considered in the GDP model were labour, infrastructure investment capital, and freight accessibility. Let $\left(L_{i} / L_{c}\right)$ be the ratio between the number of employees at department $i$ and the average number of employees, $G_{i}$ is the infrastructure investment applied by the government at department $i, A_{i}^{\mathrm{Sp}}$ is the spatial accessibility measure of department $i$, and $A_{i}^{\mathrm{Gr}}$ is the gravity accessibility measure of department $i$. Based on the obtained data, the variables were transformed to represent their nonlinear behaviour using a linear model. The empirical model that relates the GDP and the independent variables is presented in

$$
\begin{aligned}
\exp \left(\mathrm{GDP}_{i}\right)= & 9.5+0.011 \cdot \exp \left(\frac{L_{i}}{L_{c}}\right) \\
& +0.4844 \cdot \operatorname{Ln}\left(G_{i}\right)+0.1 \cdot \operatorname{Ln}\left(A_{i}^{\mathrm{Gr}}\right)
\end{aligned}
$$

This model was estimated using a multiple linear regression model, whose results are presented in Table 5.

The validity of the empirical model was evaluated using the analysis of variance (ANOVA). Table 6 shows that the independent variables can explain the GDP because the $P$ values are lower than a significance level of $\alpha=0.05$.

All the accessibility measures were tested in the empirical model. However, the measure that showed the best performance was the gravity accessibility measure, which is in line with expectations because it considers both transport costs and the exported freight demand between the origindestination pairs. The obtained model must meet two requirements: (i) a high correlation between the response and independent variables and (ii) no correlation among the independent variables. The simultaneous use of the other 


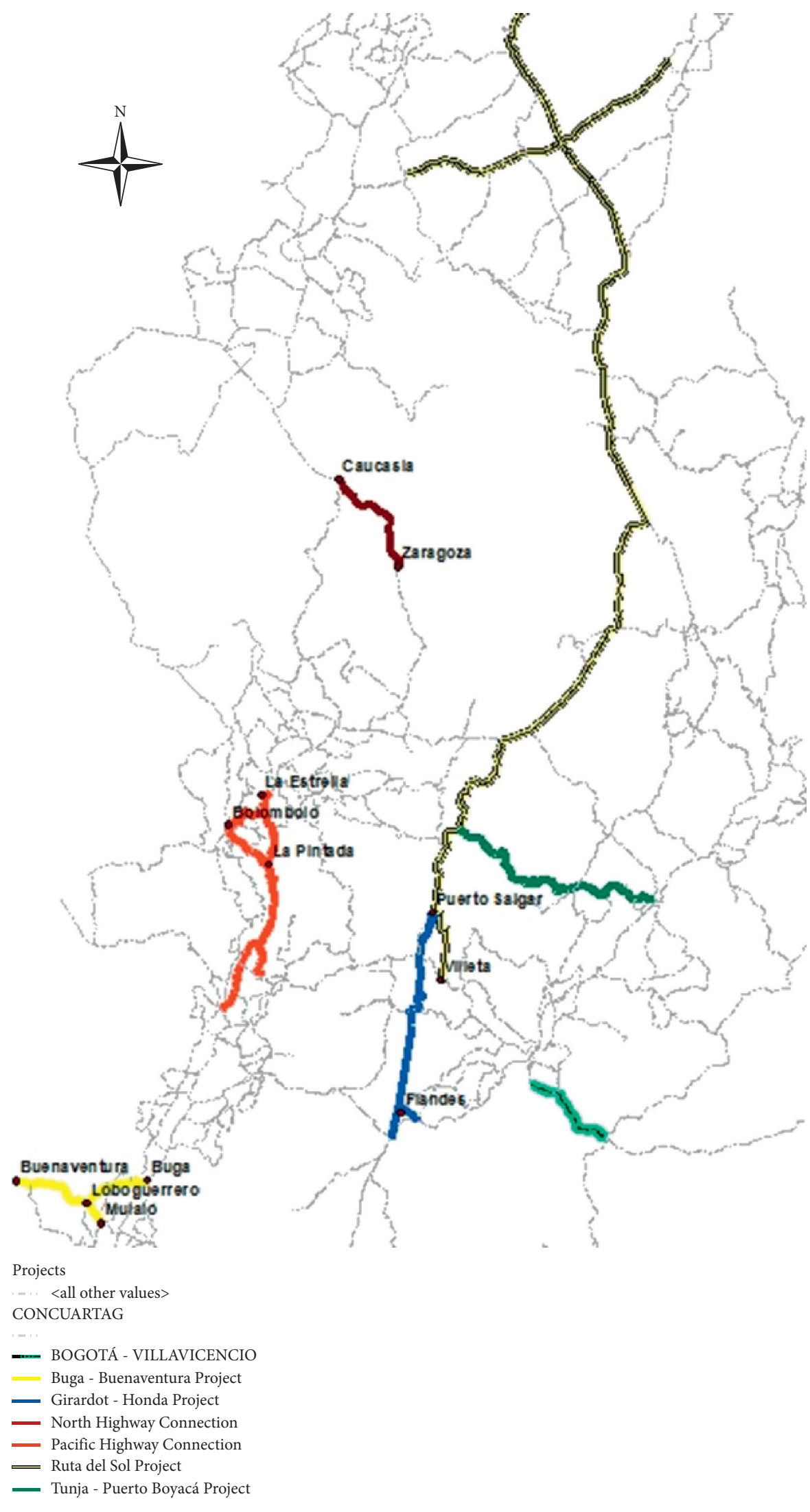

FIGURE 3: Road infrastructure projects location. 


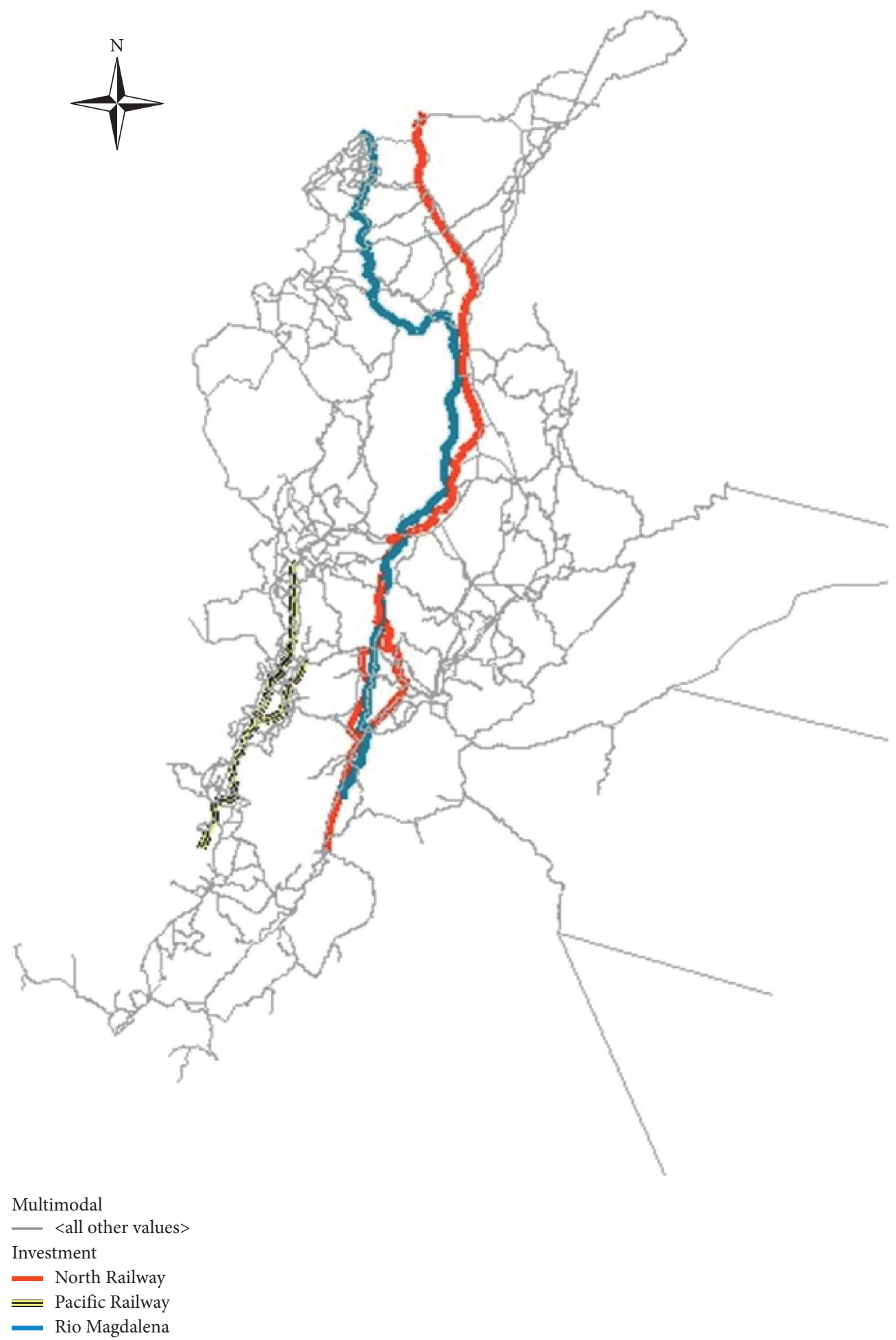

FIGURE 4: Railway and waterway infrastructure projects location.

accessibility measures was discarded because they had a strong correlation with the gravity accessibility measure. The $P$ value was used for analysing the significance of the independent variables, while the Variance Inflation Factor (VIF) was employed to test the existence of multicollinearity. The results in Table 6 show that all the independent variables explained the GDP because their $P$ values are higher than a significance level of $\alpha=0.05$. Also, there is no evidence of multicollinearity among the variables in the model because the VIF measure of the independent variables is less than 5 .

Errors in the linear regression model must meet three assumptions: normally distributed, constant variance, and independence. The first one was verified using the Shapiro-Wilk and Kolmogorov-Smirnov tests. Both tests 

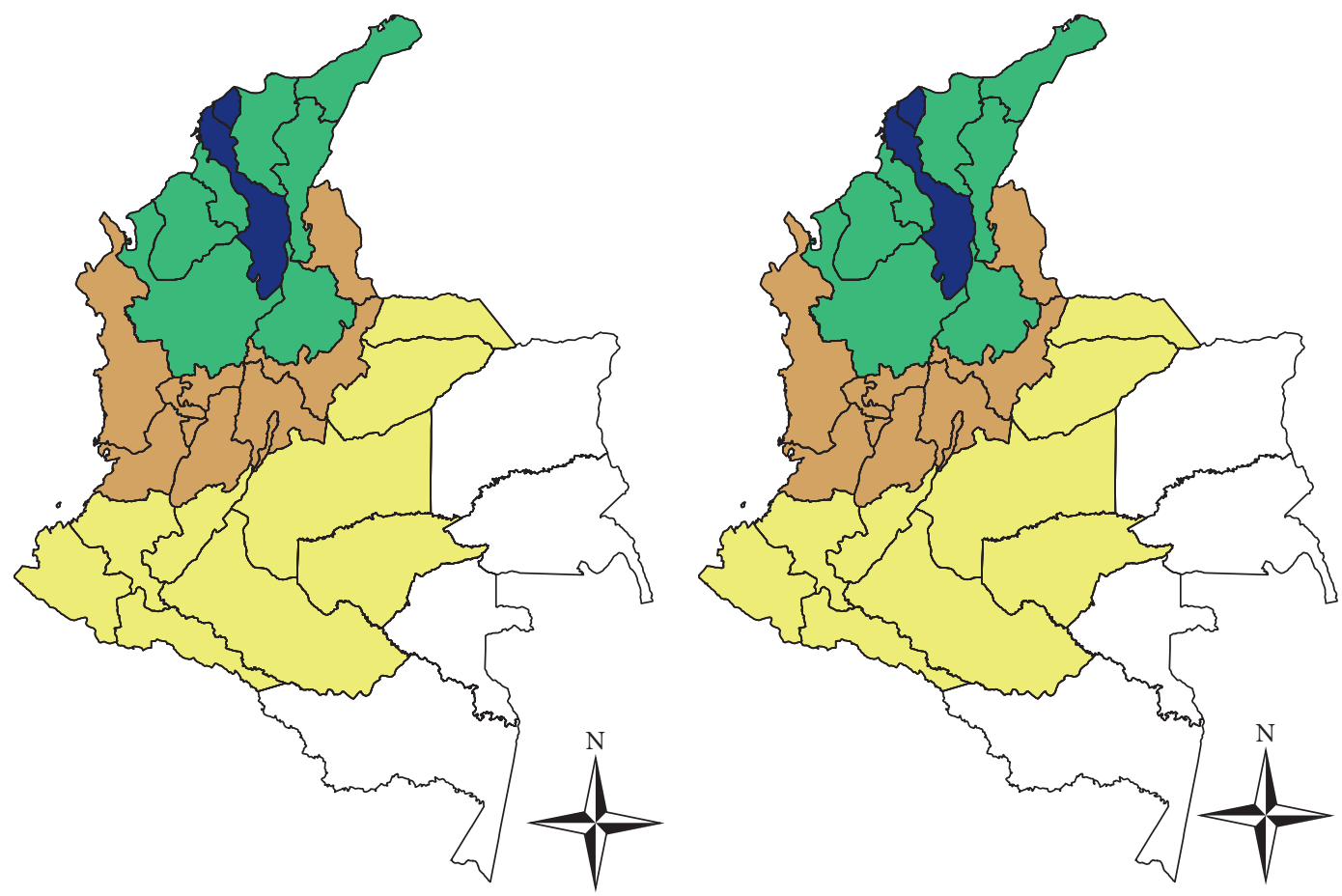

Colombia

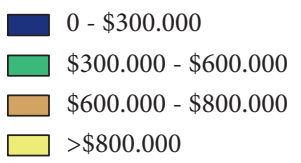

Colombia

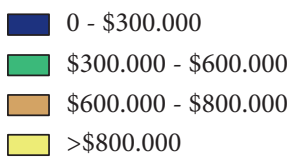

(a)

(b)

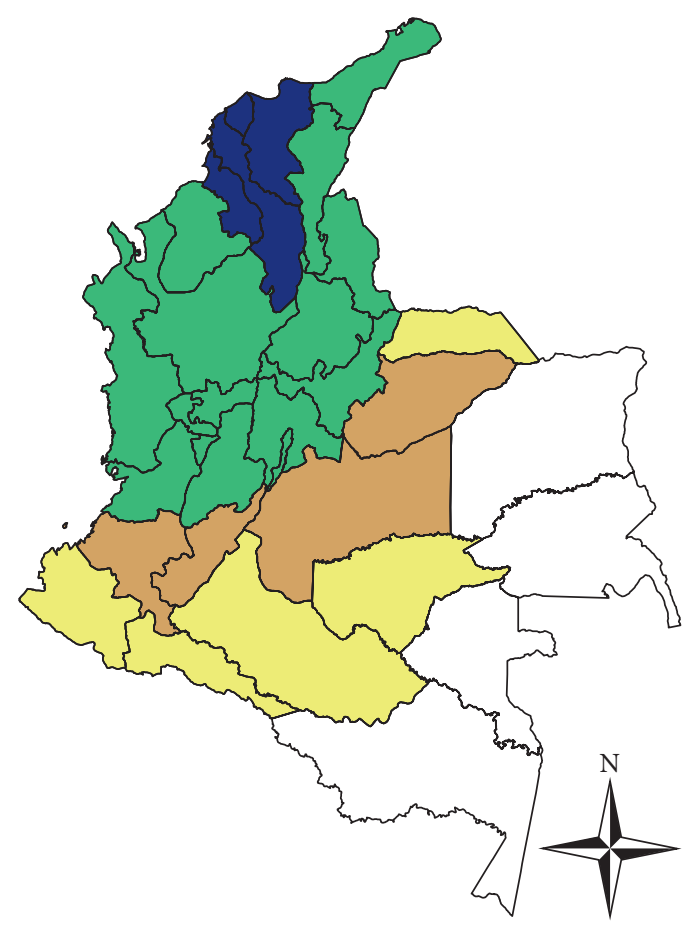

Colombia

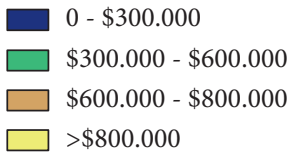

(c)

FIGURE 5: Spatial-based accessibility measure. (a) Spatial separation measure under Scenario 1, (b) spatial separation measure under Scenario 2, and (c) spatial separation measure under Scenario 3. 
TABle 3: Cumulative opportunities accessibility measure per scenario.

\begin{tabular}{lcccccc}
\hline Transport cost (USD/ton) & Scenario 1 tons & \% tons accessible & Scenario 2 tons & \% tons accessible & Scenario 3 tons & \% tons accessible \\
\hline $0-40000$ & 4696751.9 & 4.9 & 44746402.1 & 5.04 & 4911101.5 & 5.2 \\
$40000-80000$ & 48822064 & 51.88 & $48948,916.7$ & 52.01 & 49582504.4 & 52.68 \\
$80000-120000$ & 2361549.6 & 2.5 & 2185046.9 & 2.3 & 3240706.7 & 3.4 \\
Total & 55880365.5 & 59.38 & 5580365.5 & 59.38 & 3815589.3 & 61.35 \\
\hline
\end{tabular}

TABLE 4: MNL based on travel cost $\left(R^{2}=0.4607\right)$.

\begin{tabular}{lccc}
\hline Parameters & Coefficient & $T$-test & $P$ value \\
\hline$\theta_{i j}$ & 1.248 & 1.73 & 0.089 \\
$C_{i j}$ & -0.0000305 & -6.05 & 0.00000205 \\
\hline
\end{tabular}

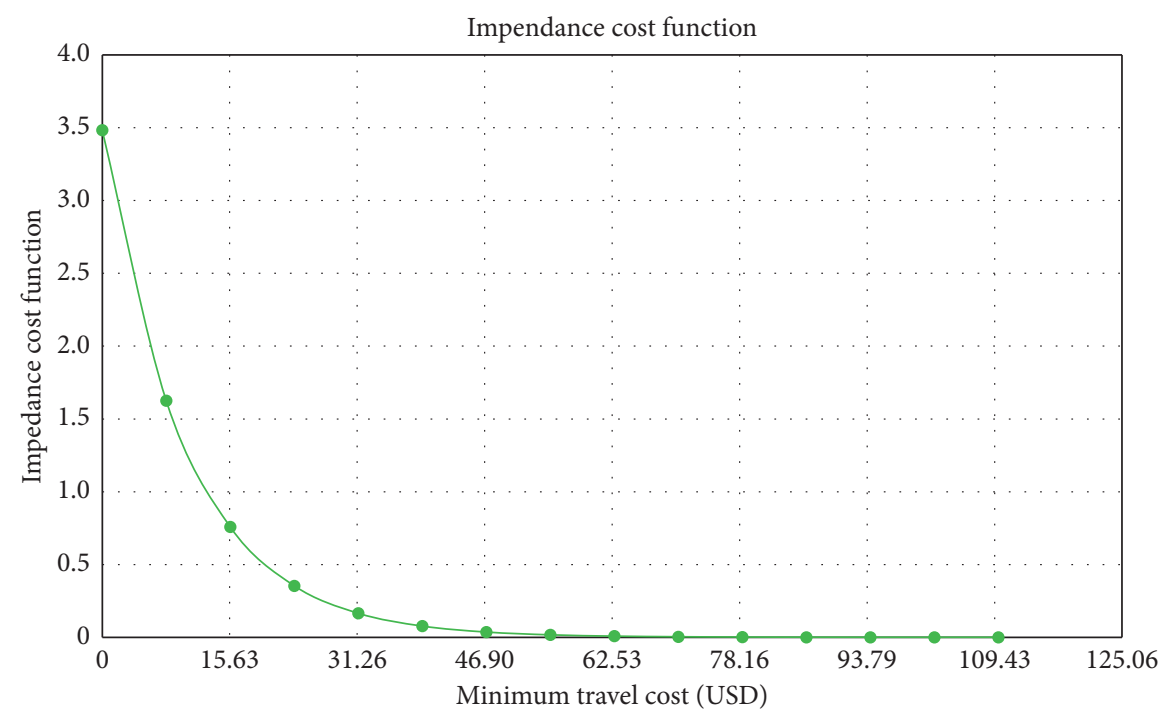

Figure 6: Impedance cost function.

concluded, with a 95\% confidence level, that errors of the empirical model are normally distributed. Both $P$ values were higher than a significance level of $\alpha=0.05$ (0.461 for the Shapiro-Wilk test and 0.2 for the Kolmogorov-Smirnov test). On the other hand, the Breusch-Pagan test was used to verify constant variance assumption among the errors; i.e., the variance remains constant in the observations so the model can predict the value of GDP. The $P$ value for this test was 0.9427 so the model meets this assumption with a significance level of $\alpha=0.05$. Finally, independence assumption was confirmed using the Ljung Box test. The test statistic was 20.89 while the critical value was 31.04 . Since the test statistic is lower that the critical value, the independence assumption is met with a significance level of $\alpha=0.05$. Figure 8 shows the errors as a time series have a random behaviour, so they are independent. Since the model fulfils all the tests supporting the assumptions, the empirical model presented in equation (6) could predict the GDP of a region.

As was expected, if the exported freight accessibility increases, the GDP also will increase. Thus, a department might produce and export more goods due to its geographical location and land use. The estimated coefficient for infrastructure investment is greater than zero. This occurs because the government spends more economic resources in some regions, which increases their GDP and allows them to receive more labour, materials, capital, and equipment.

4.3. Analysis of Scenarios. The analysis of scenarios consists of evaluating the road, maritime, and railways network projects mentioned in Table 2 using their investment cost, percentage of GDP growth, and accessibility growth. The impact on the GDP model due to a road infrastructure project depends on the principal intervention that will be implemented. The investment increases the maximum road speed and, consequently, modifies the transport cost of a route between the regions and the seaports. This investment also impacts the GDP of a department since it influences the gravity accessibility measure that considers the transport cost, as shown in equation (6). GDP and accessibility growth were calculated for each project, as shown in Table 7.

A cost-benefit relationship analysis was made for each investment project. The results show that investments in road infrastructure have little impact on improving the country's competitiveness because the investment cost is higher than the increase in GDP and accessibility. The 

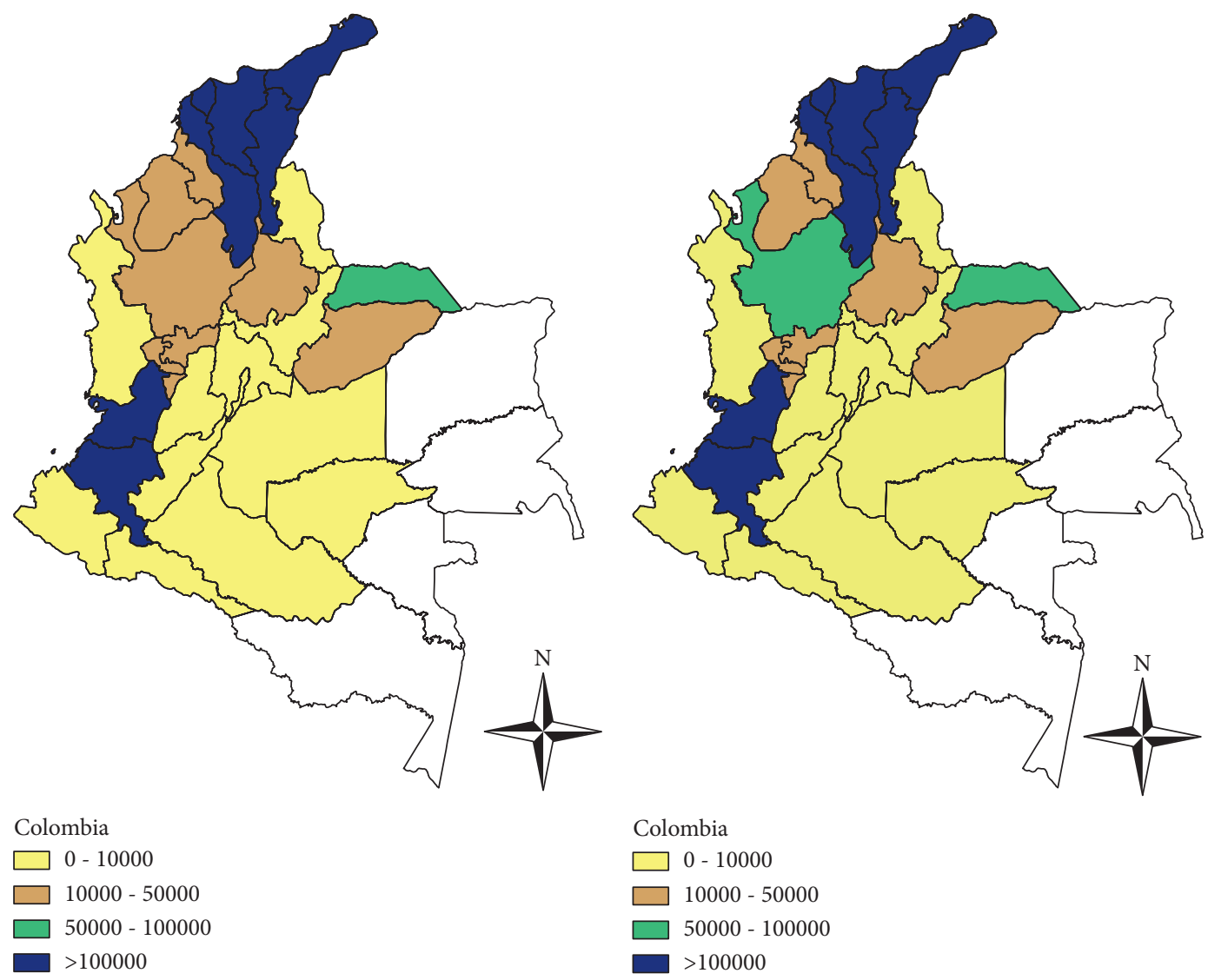

Colombia

$\square 0$ - 10000

$\square 10000-50000$

$\square 0000-100000$

$\square>100000$

(a)

(b)

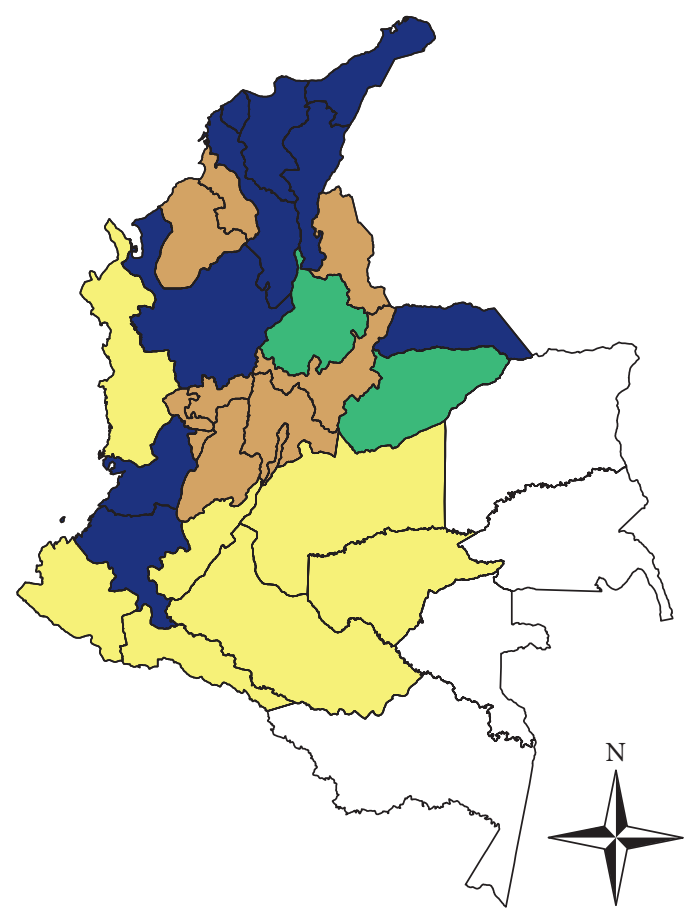

Colombia

$\square 0$ - 10000

$\square 10000-50000$

$\square 50000-100000$

$\square>100000$

(c)

FIGURE 7: Gravity-based accessibility measure. (a) Gravity-based measure under Scenario 1. (b) Gravity-based measure under Scenario 2. (c) Gravity-based measure under Scenario 3. 
TABLE 5: Empirical GDP model (adjusted $R^{2}=0.6574$ ).

\begin{tabular}{lcccc}
\hline Parameters & Coefficient & T-test & $P$ value & \\
\hline Constant & 9.50 & 5.38 & 0.000017 & VIF \\
$\exp \left(L_{i} / L_{c}\right)$ & 0.011 & 4.04 & 0.00049 & 1.026 \\
$\operatorname{Ln}\left(G_{i}\right)$ & 0.4844 & 3.069 & 0.0054 & 1.209 \\
$\operatorname{Ln}\left(A_{i}^{\mathrm{Gr}}\right)$ & 0.10 & 3.066 & 0.00546 & 1.181 \\
\hline
\end{tabular}

TABLe 6: ANOVA for the empirical model.

\begin{tabular}{|c|c|c|c|c|c|}
\hline Source of variation & Degrees of freedom & Sum of squares & Mean square & $F$ value & $P$ value \\
\hline Regression & 3 & 24.66 & 8.22 & 17.63 & $p \leq 0.001$ \\
\hline Error & 23 & 10.72 & 0.46 & $X \mid$ & \\
\hline Total & 35.38 & 26 & & & \\
\hline
\end{tabular}

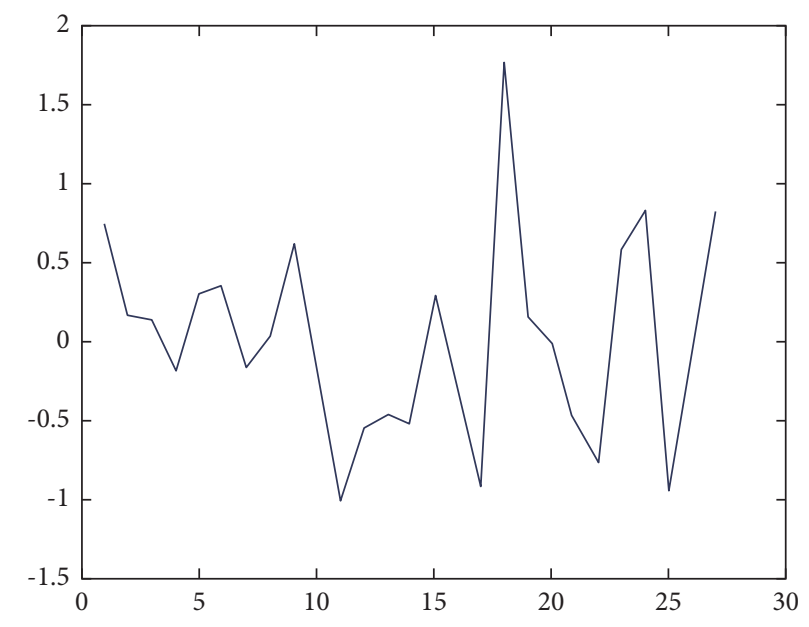

FigURE 8: Errors vs. order of observations.

TABLE 7: GDP and accessibility growth for road infrastructure projects.

\begin{tabular}{lccc}
\hline Infrastructure projects & Cost of intervention (USD) & GDP growth (\%) & Accessibility growth (\%) \\
\hline Ruta del Sol project & $2,228,841,426.47$ & 0.0718 & 0.9103 \\
Buga-Buenaventura project & $960,121,044.04$ & 0.0517 & 0.0697 \\
Girardot-Honda project & $484,365,393.84$ & 0.0328 & 0.0100 \\
Tunja-Puerto Boyaca project & $77,014,096.41$ & 0.0000004 & 0.0000001 \\
North Highway connection & $406,680,130.18$ & 0.0069 & 0.0022 \\
Bogota-Villavicencio project & $993,471,645.72$ & 0.005 & 0.0002 \\
Pacific Highway connection & $1,644,102,392.55$ & 0.0165 & 0.0046 \\
Pacific Railway project & $3,534,786,208.98$ & 1.05 & 1.382 \\
North Railway project & $5,923,341,112.37$ & 1.36 & 1.644 \\
Dredging of the Magdalena River & $1,000,848,000.00$ & 0.99 & 1.36 \\
\hline
\end{tabular}

investments that produce a sounder benefit are those that have higher costs since they are the ones that add new roads, tunnels, or bridges, like the Ruta del Sol project. On the other hand, the Tunja-Puerto Boyaca project is the one with the lowest impact in both GDP and accessibility growth because it is a minimum route to reach the most important seaports of the country, as can be seen in Figure 3. It is worth mentioning that the Buga-Buenaventura project has the second-highest GDP growth because it is a crucial route from all origins to reach the Buenaventura seaport, one of the most important of the country.

Investment in railways for the western region of the country offers twice the benefits of the most profitable road project. However, they increase the country's GDP and the region's accessibility twice as much as it would increase if only roads were improved. In other words, there is no difference in the cost-benefit relationship between the types of projects since the investment cost is proportional to the 
increase in GDP and accessibility. Dredging the Magdalena River and investing in improving the Magdalena river trunk represent an excellent profitable cost-benefit alternative since this project crosses the country from north to south and connects different regions, as shown in Figure 4.

The results show how the GDP and accessibility growth can be analysed given the implementation of new investment in infrastructure. The proposed methodology can help prioritise investment projects due to limited resources of government authorities, especially in Global South countries. Although the study uses a specific list of variables in the analysis, it is statistically proved that the representation of the model is quite relevant. Moreover, the model was purposely developed to show the relationship between the geographical accessibility of freight to regions and the project appraisal towards economic growth, in terms of GDP potential growth.

\section{Conclusion}

This paper analyses the relationship between the effects of infrastructure investment and Colombian productivity in terms of savings in travelling cost generated by projects and public expenditure, using accessibility measures. Unlike other studies, this approach evaluates changes in GDP due to the implementation of new infrastructure projects under constraints on investment budget. Transport investment projects can be counterproductive by draining the resources of an economy instead of creating wealth and additional opportunities. Thus, the importance of finding models to make decisions on how to choose the most appropriate investment project becomes extremely relevant, especially in the Global South context.

Accessibility measures were calculated, and the most appropriate measure was selected. Although these measures have been widely studied in the context of passenger transportation, this paper shows how to efficiently implement them in freight transportation and its relationship to economic growth, expressed in GDP. Three accessibility measures were used and this study showed how the gravitybased measure yields better representation and description of the relationship between access to regions and the GDP. A linear model was determined for relating freight demand, travel cost, and time and, finally, a linear regression model between GDP and labour, investment, and accessibility measures was developed, based on a transformation of these nonlinear variables. This leads to evaluating which zone and type of investment infrastructure should be prioritized (in the context of budget constraints) based on the economic growth of the country.

Results from the case study suggest that a specific region could be more competitive than others because of its geographic location. Additionally, multimodal transport reduces transport costs and increases accessibility more than road transport. Based on the MNL model, it can be established that the changes in the impedance function are practically null for values higher than 37.53 USD. That is, the investments that have significant changes in the freight demand between origin-destination pairs are those that reduce travel cost to lower values than the mentioned one. Therefore, regions located far from seaports increase GDP in higher proportion than regions with high accessibility when investment in transport infrastructure takes place. In other words, the farthest zones obtain higher benefits due to the gains in freight transportation accessibility produced by infrastructure investments compared to regions that are closer to seaports. The results show the increase in productivity from the access to a larger and more diverse base of inputs, such as raw materials, components, energy or labour, and broader markets for diverse outputs, in terms of intermediate and finished goods. Although the level of impact may be case-specific, the methods are relevant and could be extended and generalised to any other region with any type of economic development.

The cost savings caused by road and multimodal transport projects were compared. Transport infrastructures are capital intensive fixed assets; therefore, they are particularly vulnerable to misallocations and ineffective investments. A clear example is that the implementation of road projects does not have a substantial impact on transportation costs. However, multimodal transport represents a relevant savings impact on generalised transportation costs because it provides a competitive solution for developing the logistic infrastructure [76]. Spatial separation and gravity accessibility measures established that economic production and transport costs are correlated because a zone with low spatial separation measurements implies low gravity accessibility. The former result suggests that economic activities are proportional to their location in the network. Where there is a high level of accessibility and where transportation networks are already extensive, further investments usually result in marginal improvements. Multimodal transport represents a reduction in the transport cost, principally in the regions located in the central zone of the country. Nevertheless, road infrastructure improvements do not abruptly change accessibility. In this case, there are zones that present major changes depending on the type of investment.

Further research should consider competency with alternative transport modes [77] and other components in the generalised transport cost, such as the frequency of shipping, maritime freight rate, maritime transit time, port charges, local content taxes, expected changes in the value of land due to investment, and demand growth due to infrastructure investment. Additionally, an individual accessibility measure could be used at each port. Restrictions in the maritime operation can also be included in the proposed methodology, such as the season of the year and ships' size given the capacity of specific ports. Other variables were not considered in this study, such as changes in foreign trade routes that may affect our economy, which were considered stable and may also be part of further research. Also, future studies 
should focus on exploring the relationship between GDP and other explanatory variables such as competitiveness, sales prices, and accessibility under different contexts.

\section{Data Availability}

The datasets are available at https:/github.com/jubizm/ Transport_infrastructure_Colombia.

\section{Conflicts of Interest}

The authors declare that there are no conflicts of interest regarding the publication of this study.

\section{References}

[1] J. J. Laird and A. J. Venables, "Transport investment and economic performance: a framework for project appraisal," Transport Policy, vol. 56, pp. 1-11, 2017.

[2] A. Maciulis, A. V. Vasiliauskas, and G. Jakubauskas, "The impact of transport on the competitiveness of national economy," Transport, vol. 24, pp. 93-99, 2009.

[3] B. Rokicki and M. Stepniak, "Major transport infrastructure investment and regional economic development-an accessibility-based approach," Journal of Transport Geography, vol. 72, pp. 36-49, 2018.

[4] T. F. Halaszovich and A. Kinra, "The impact of distance, national transportation systems and logistics performance on FDI and international trade patterns: results from Asian global value chains," Transport Policy, vol. 98, pp. 35-47, 2020.

[5] R. Vickerman, "Transit investment and economic development," Research in Transportation Economics, vol. 23, no. 1, pp. 107-115, 2008.

[6] J.-P. Rodrigue, "Transportation and the geographical and functional integration of global production networks," Growth and Change, vol. 37, no. 4, pp. 510-525, 2006.

[7] M. Mesquita Moreira, J. S. Blyde, C. Volpe Martincus, and D. Molina, Too Far to Export: Domestic Transport Costs and Regional Export Disparities in Latin America and the Caribbean, IADB, Washington, DC, USA, 2013.

[8] L. Berrio, V. Cantillo, and J. Arellana, "Strategic modelling of passenger transport in waterways: the case of the Magdalena river," Transport, vol. 34, no. 3, pp. 215-224, 2019.

[9] L. Vega, V. Cantillo, and J. Arellana, "Assessing the impact of major infrastructure projects on port choice decision: the Colombian case," Transportation Research Part A: Policy and Practice, vol. 120, pp. 132-148, 2019.

[10] P. Sahoo, R. K. Dash, G. Nataraj et al., "Infrastructure development and economic growth in China," Institute of Developing Economies Discussion Paper, vol. 261, 2010.

[11] E. Cascetta, A. Cartenì, I. Henke, and F. Pagliara, "Economic growth, transport accessibility and regional equity impacts of high-speed railways in Italy: ten years ex post evaluation and future perspectives," Transportation Research Part A: Policy and Practice, vol. 139, pp. 412-428, 2020.

[12] E. N. Robson, K. P. Wijayaratna, and V. V. Dixit, "A review of computable general equilibrium models for transport and their applications in appraisal," Transportation Research Part A: Policy and Practice, vol. 116, pp. 31-53, 2018.

[13] T. R. Lakshmanan, "The broader economic consequences of transport infrastructure investments," Journal of Transport Geography, vol. 19, no. 1, pp. 1-12, 2011.
[14] Z. Wen and J. Chen, "A cost-benefit analysis for the economic growth in China," Ecological Economics, vol. 65, no. 2, pp. 356-366, 2008.

[15] M. Ali, K. Osra, and J. Siegmann, "Proposed high-speed rail line between Cairo-Alexandria: cost-benefit analysis," CivilComp Proceedings, vol. 110, 2016.

[16] K. Martens and F. Di Ciommo, "Travel time savings, accessibility gains and equity effects in cost-benefit analysis," Transport Reviews, vol. 37, no. 2, pp. 152-169, 2017.

[17] I. Henke, A. Carteni, and L. Di Francesco, "A sustainable evaluation processes for investments in the transport sector: a combined multi-criteria and cost-benefit analysis for a new highway in Italy," Sustainability, vol. 12, no. 23, p. 9854, 2020.

[18] E. Kim, G. J. D. Hewings, and C. Hong, "An application of an integrated transport network-multiregional CGE model: a framework for the economic analysis of highway projects," Economic Systems Research, vol. 16, no. 3, pp. 235-258, 2004.

[19] E. Kim, G. J. D. Hewings, and H. Amir, "Economic evaluation of transportation projects: an application of financial computable general equilibrium model," Research in Transportation Economics, vol. 61, pp. 44-55, 2017.

[20] W. Hansen, "Developing a new spatial computable general equilibrium model for Norway," in Proceedings of the European Transport Conference, Glasgow, UK, October 2010.

[21] Z. Chen, "Measuring the regional economic impacts of highspeed rail using a dynamic SCGE model: the case of China," European Planning Studies, vol. 27, no. 3, pp. 483-512, 2019.

[22] T. Hiramatsu, "Unequal regional impacts of high speed rail on the tourism industry: a simulation analysis of the effects of Kyushu Shinkansen," Transportation, vol. 45, no. 2, pp. 677-701, 2018.

[23] Z. H. Munim and H.-J. Schramm, "The impacts of port infrastructure and logistics performance on economic growth: the mediating role of seaborne trade," Journal of Shipping and Trade, vol. 3, no. 1, pp. 1-19, 2018.

[24] M. Duzbaievna Sharapiyeva, A. Antoni, and R. Yessenzhigitova, "The impact of port transport-logistics infrastructure and LPI for economic growth," Pomorstvo: Scientific Journal of Maritime Research, vol. 33, no. 1, pp. 63-75, 2019.

[25] P. Deng, S. Lu, and H. Xiao, "Evaluation of the relevance measure between ports and regional economy using structural equation modeling," Transport Policy, vol. 27, pp. 123-133, 2013.

[26] X. Jiang, X. He, L. Zhang, H. Qin, and F. Shao, "Multimodal transportation infrastructure investment and regional economic development: a structural equation modeling empirical analysis in China from 1986 to 2011," Transport Policy, vol. 54, pp. 43-52, 2017.

[27] D. A. Aschauer, "Is public expenditure productive?" Journal of Monetary Economics, vol. 23, no. 2, pp. 177-200, 1989.

[28] C. Karlsson and L. Pettersson, "Regional productivity and accessibility to knowledge and dense markets," 2005.

[29] K. Yamaguchi, "Inter-regional air transport accessibility and macro-economic performance in Japan," Transportation Research Part E: Logistics and Transportation Review, vol. 43, no. 3, pp. 247-258, 2007.

[30] S. Fan and C. Chan-Kang, "Regional road development, rural and urban poverty: evidence from China," Transport Policy, vol. 15, no. 5, pp. 305-314, 2008.

[31] S. Dercon, D. O. Gilligan, J. Hoddinott, and T. Woldehanna, "The impact of agricultural extension and roads on poverty and consumption growth in fifteen Ethiopian villages," 
American Journal of Agricultural Economics, vol. 91, no. 4, pp. 1007-1021, 2009.

[32] D. Martín-Barroso, J. A. Nuñez, and F. J. Velázquez, The Effect on Firms' Productivity of Accessibility. The Spanish Manufacturing Sector, ERSA Conference Papers ersa13p1123, European Regional Science Association, Louvain-la-Neuve, Belgium, 2013.

[33] J. Baños, P. González, and M. Mayor, "Productivity and accessibility of road transport infrastructure in Spain: a spatial econometric approach," Technical Report, Working paper, University of Oviedo, Oviedo, Spain, 2013.

[34] H. Itoh, "An impact analysis of logistics accessibility improvements on the productivity of manufacturing sectors," in Proceedings of the International Conference on Transportation and Logistics (T-LOG 2014), pp. 1-17, Bangkok, Thailand, June 2014.

[35] D. Martín-Barroso, J. A. Núñez-Serrano, and F. J. Velázquez, "The effect of accessibility on productivity in Spanish manufacturing firms," Journal of Regional Science, vol. 55, no. 5, pp. 708-735, 2015.

[36] M. H. Salas-Olmedo, P. García, and J. Gutiérrez, "Accessibility and transport infrastructure improvement assessment: the role of borders and multilateral resistance," Transportation Research Part A: Policy and Practice, vol. 82, pp. 110-129, 2015.

[37] C. P. Ng, T. H. Law, S. V. Wong, and S. Kulanthayan, "Relative improvements in road mobility as compared to improvements in road accessibility and economic growth: a crosscountry analysis," Transport Policy, vol. 60, pp. 24-33, 2017.

[38] B. R. D. K. Agbelie, "An empirical analysis of three econometric frameworks for evaluating economic impacts of transportation infrastructure expenditures across countries," Transport Policy, vol. 35, pp. 304-310, 2014.

[39] F. P. Van den Heuvel, L. Rivera, K. H. van Donselaar et al., "Relationship between freight accessibility and logistics employment in us counties," Transportation Research Part A: Policy and Practice, vol. 59, pp. 91-105, 2014.

[40] A. Verhetsel, R. Kessels, P. Goos, T. Zijlstra, N. Blomme, and J. Cant, "Location of logistics companies: a stated preference study to disentangle the impact of accessibility," Journal of Transport Geography, vol. 42, pp. 110-121, 2015.

[41] C. Ng, T. Law, F. Jakarni, and S. Kulanthayan, "Road infrastructure development and economic growth," in IOP Conference Series: Materials Science and Engineering, vol. 512, Article ID 012045, IOP Publishing, Bristol, UK.

[42] A. J. Venables, "Evaluating urban transport improvements: cost-benefit analysis in the presence of agglomeration and income taxation," Journal of Transport Economics and Policy, vol. 41, pp. 173-188, 2007.

[43] A. Ribeiro, A. P. Antunes, and A. Páez, "Road accessibility and cohesion in lagging regions: empirical evidence from Portugal based on spatial econometric models," Journal of Transport Geography, vol. 18, no. 1, pp. 125-132, 2010.

[44] P. Rietveld, "Spatial economic impacts of transport infrastructure supply," Transportation Research Part A: Policy and Practice, vol. 28, no. 4, pp. 329-341, 1994.

[45] C. Karlsson, U. Grasjo, M. Andersson et al., "Regional knowledge accessibility and regional economic growth," in Proceedings of the 46th Conference of the European Regional Science Association, vol. 30, Volos, Greece, August 2006.

[46] B. Linneker and N. Spence, "Road transport infrastructure and regional economic development," Journal of Transport Geography, vol. 4, no. 2, pp. 77-92, 1996.
[47] A. Holl, "Manufacturing location and impacts of road transport infrastructure: empirical evidence from Spain," Regional Science and Urban Economics, vol. 34, no. 3, pp. 341-363, 2004.

[48] J. Jiao, J. Wang, F. Jin, and C. Du, "Understanding relationship between accessibility and economic growth: a case study from China (1990-2010)," Chinese Geographical Science, vol. 26, no. 6, pp. 803-816, 2016.

[49] J. Gutiérrez, "Location, economic potential and daily accessibility: an analysis of the accessibility impact of the highspeed line Madrid-Barcelona-French border," Journal of Transport Geography, vol. 9, no. 4, pp. 229-242, 2001.

[50] F. B. Khalili, A. P. Antunes, and A. S. Mohaymany, "Evaluating interregional freight accessibility conditions through the combination of centrality and reliability measures," Journal of Transport Geography, vol. 83, Article ID 102665, 2020.

[51] I. Thomas, J.-P. Hermia, T. Vanelslander, and A. Verhetsel, "Accessibility to freight transport networks in Belgium: a geographical approach," Tijdschrift voor Economische en Sociale Geografie, vol. 94, no. 4, pp. 424-438, 2003.

[52] J. T. Bowen Jr., "Moving places: the geography of warehousing in the us," Journal of Transport Geography, vol. 16, no. 6, pp. 379-387, 2008.

[53] H. Lim and J.-C. Thill, "Intermodal freight transportation and regional accessibility in the United States," Environment and Planning A: Economy and Space, vol. 40, no. 8, pp. 2006-2025, 2008.

[54] J.-C. Thill and H. Lim, "Intermodal containerized shipping in foreign trade and regional accessibility advantages," Journal of Transport Geography, vol. 18, no. 4, pp. 530-547, 2010.

[55] A. Africani, R. Delpiano, H. Drewello, A. Fontanili, M. Huschebeck, and D. Taake, "Comparative analysis of accessibility for freight transport in corridor regions: results of two case studies," in Integrated Spatial and Transport Infrastructure Development, pp. 133-146, Springer, Berlin, Germany, 2016.

[56] L. Guo and Z. Yang, "Evaluation of foreign trade transport accessibility for mainland China," Maritime Policy \& Management, vol. 45, no. 1, pp. 34-52, 2018.

[57] A. Lopez, J. Tornet, and C. D. Paternina-Arboleda, "The insertion of a multimodal transportation system to improve the logistics competitiveness of agricultural commodities in a Colombian region. Foreign commerce and value added," Contemporary Engineering Sciences, vol. 11, no. 36, pp. 1757-1769, 2018.

[58] L. Marzuez, V. Cantillo, and C. D. Paternina-Arboleda, "Accessibility variables in freight generation models for agricultural products: an elastic nationwide model for evaluating the impact of infrastructure projects," Technical Report, Transportation Research Board, Washington, DC, USA, 2017.

[59] K. T. Geurs and B. van Wee, "Accessibility: perspectives, measures and applications," The Transport System and Transport Policy: An Introduction, p. 207, Edward Elgar Publishing, Cheltenham, UK, 2013.

[60] K. T. Geurs and B. Van Wee, "Accessibility evaluation of landuse and transport strategies: review and research directions," Journal of Transport Geography, vol. 12, no. 2, pp. 127-140, 2004.

[61] J. Scheurer and C. Curtis, Accessibility Measures: Overview and Practical Applications, Vol. 52, Department of Urban and Regional Planning, Curtin University, Perth, Australia, 2007.

[62] M. S. Serag and F. E. Al-Tony, "Modeling international freight transport through the ports and lands of Arab countries," 
Alexandria Engineering Journal, vol. 52, no. 3, pp. 433-445, 2013.

[63] C. Bhat, S. Handy, K. Kockelman, H. Mahmassani, Q. Chen, and L. Weston, Urban Accessibility Index: Literature Review, Center of Transportation Research, University of Texas at Austin, Austin, TX, USA, 2000.

[64] G. Mankiw, Macroeconomía, (6ta Edición), Antoni Bosch, España, 2006.

[65] Y. Zou, "Empirical studies on the relationship between public and private investment and GDP growth," Applied Economics, vol. 38, no. 11, pp. 1259-1270, 2006.

[66] T. Khatun and S. Afroze, "Relationship between real GDP and labour \& capital by applying the Cobb-Douglas production function: a comparative analysis among selected Asian countries," Journal of Business, vol. 37, 2016.

[67] Y. Gao, Y. Zhang, H. Li, T. Peng, and S. Hao, "Study on the relationship between comprehensive transportation freight index and GDP in China," Procedia engineering, vol. 137, pp. 571-580, 2016.

[68] Superintendent of Ports and Transport and Cargo Movement for Colombian Maritime Ports, "Consolidated report of December 2014-accumulated movement from January to December of 2014," 2015, https://www.supertransporte.gov. $\mathrm{co} /$.

[69] J. Cantillo, V. Cantillo, and J. Arellana, "Modelling with joint choice of ports and countries of origin and destination: application to Colombian ports," Maritime Policy \& Management, vol. 45 , no. 6 , pp. $720-738,2018$

[70] DIAN, “Official record of exports (2013-2014)," 2014, https:// www.dian.gov.co/.

[71] L. G. Márquez, "Optimización de una red de transporte combinado para la exportación del carbón del interior de Colombia (optimization of a combined export coal transport network from the interior of Colombia)," Revista EIA, vol. 8, pp. 103-113, 2013.

[72] L. G. Márquez Díaz and V. M. Cantillo Maza, "Evaluación de los parámetros de las funciones de costo en la red estratégica de transporte de carga para Colombia," Ingenieria y Desarrollo, vol. 29, 2011.

[73] V. Cantillo, J. Arellana, and J. Visbal, "Analysis on the determinants of shipment size and type-of-truck choices using a discrete-continuous hybrid model," International Journal of Shipping and Transport Logistics, vol. 10, no. 4, pp. 406-428, 2018.

[74] DANE, "Gross production data from 2013," 2013, https:// www.dane.gov.co/.

[75] DANE, "Number of employee's data from 2013," 2013, https://www.dane.gov.co/.

[76] DNP, "Report of regionalization inversion budget 2013," 2013, https://www.dnp.gov.co/.

[77] A. M. Larranaga, J. Arellana, and L. A. Senna, "Encouraging intermodality: a stated preference analysis of freight mode choice in rio grande do sul," Transportation Research Part A: Policy and Practice, vol. 102, pp. 202-211, 2017. 